\title{
40. DEVELOPMENT OF LATITUDINAL THERMAL GRADIENTS DURING THE OLIGOCENE: OXYGEN-ISOTOPE EVIDENCE FROM THE SOUTHWEST PACIFIC ${ }^{1}$
}

\author{
Margaret G. Murphy and James P. Kennett, University of Rhode Island ${ }^{2}$
}

\begin{abstract}
The late Eocene through earliest Miocene stable-isotope composition of southwest Pacific microfossils has been examined in a traverse of high-quality sedimentary sequences ranging from subantarctic (DSDP Site 277) through temperate regions (DSDP Sites 592 and 593). Changes in oxygen-isotope values, measured in benthic and planktonic foraminifers, document the Oligocene development and strengthening of latitudinal thermal zonation from water masses with broad temperature gradients during the Eocene to the steeper gradients and more distinct latitudinally distributed surface water-mass belts of the Neogene.

The oxygen-isotope records can be divided into three intervals: late Eocene, early Oligocene, and middle to late Oligocene. Each interval represents a successive stage in the evolution of latitudinal thermal gradients between subantarctic and temperate regions in the Southern Hemisphere.

During the late Eocene, oxygen-isotope values at subantarctic Site 277 were similar to those at temperate Sites 592 and 593. The isotope values suggest that, although the inferred paleotemperatures at Site 277 are slightly cooler on average than those at the temperate sites, there is no evidence for a major thermal boundary between the regions at this time. All three sites record the well-known oxygen-isotope enrichment of $\sim 1 \%_{0}$ in both planktonic and benthic foraminifers in close association with the Eocene/Oligocene boundary. In contrast to the earliest Oligocene enrichments in the planktonic and benthic oxygen-isotope composition at Site 277, more northern Sites 592 and 593 exhibit a depletion through the early-middle Oligocene. This documents the beginning of thermal segregation as subantarctic waters cooled relative to those at temperate latitudes. During the Oligocene, this surface-water differentiation continued, as measured by planktonic $\delta^{18} \mathrm{O}$ values. The oxygen-isotope records of the benthic foraminifers also began to diverge in the earliest Oligocene. The most enriched oxygen-isotope values in all records cluster in the middle Oligocene, marked by oscillating episodes of enrichments $>0.5 \%$ occurring most prominently in the subantarctic record of Site 277. These values can be interpreted as recording either the coldest oceanic temperatures of the Paleogene and/or accumulations of Antarctic ice. After this interval, latitudinal thermal differentiation developed rapidly during the middle Oligocene, especially in the surface waters which actually warmed in temperate areas. If the enriched Oligocene oxygen-isotope values indicate that ice had accumulated, this ice must have disappeared by the early Miocene, when depleted oxygen-isotope values suggest very warm conditions.

The data presented in this chapter document the progressive increase of latitudinal temperature gradients from the late Eocene through the late Oligocene. This pattern of increasing isotopic offset between latitudinally distributed southwest Pacific sites is linked to the establishment and strengthening of the Circum-Antarctic Current, previously considered to have developed during the middle to late Oligocene. The intensification of this current system progressively decoupled the warm subtropical gyres from cool polar circulation, in turn leading to increased Antarctic glaciation.
\end{abstract}

\section{INTRODUCTION}

The record of global Cenozoic climate generally shows the progressive cooling and glaciation of the polar regions. High-latitude cooling, and perhaps some warming in the tropics, led to an increased latitudinal thermal gradient during the Cenozoic. This scenario has been developed from several lines of evidence, including comparisons of changing isotopic values between high and low latitudes during the Cenozoic (Savin et al., 1975; Shackleton and Kennett, 1975; Loutit et al., 1984). Biogeographic patterns of planktonic fossil groups changed from a few broadly distributed provinces in the Paleogene to more numerous, distinct, narrow belts in the Neogene. The changing faunal and floral patterns also indicate cooling of the high-latitude regions as the Antarctic water mass developed (Kaneps, 1975; Kennett, 1978; Sancetta, 1979; Wise et al., 1982).

\footnotetext{
${ }^{1}$ Kennett, J. P., von der Borch, C. C., et al., Init. Repts. DSDP, 90: Washington (U.S. Govt, Printing Office).

Address: Graduate School of Oceanography, University of Rhode Island, Narragansett, RI 02882-1197.
}

The cooling of high southern latitudes was a direct result of the developing Circum-Antarctic Current and the related thermal isolation of the Antarctic continent (Kennett, 1977; Kvasov and Verbitsky, 1981). Thus, the development and steepening of the latitudinal thermal gradient was closely linked to development of this $\mathrm{Cir}$ cum-Antarctic Current system. Previous work in the Australasian sector of the Southern Ocean indicated major development of this system during the middle to late Oligocene (Kennett, 1977; 1978), when deep circumantarctic circulation started south of Tasmania and the South Tasman Rise (Kennett et al., 1975). The system continued to expand and intensify as Australia continued its northward drift and the Scotia Sea and Drake Passage became less constricted. The last major Antarctic gateway probably opened through the Drake Passage during the late Oligocene (Barker and Burrell, 1977; Sclater et al., in press). The resulting thermal isolation of Antarctica led to increased glaciation, continental ice accumulation, and sea-ice formation. This, in turn, increased albedo, leading to further cooling, to increased wind strength, and to augmented psychrospheric bottom-water production. 
The purpose of this chapter is to present oxygen- and carbon-isotope data for three sites that form a latitudinal traverse spanning about $12^{\circ}$ in the Oligocene. This transect incorporates the modern subantarctic through northern temperate regions. We compared $\delta^{18} \mathrm{O}$ data between these sites to decipher changes in latitudinal thermal gradients through the Oligocene in the southwest Pacific and to examine the interrelationships between this thermal history and the developing Circum-Antarctic Current.

Two undisturbed late Eocene to Oligocene sediment sections were collected during Deep Sea Drilling Project (DSDP) Leg 90 (Fig. 1) using the extended core barrel apparatus (XCB). One section (Site 592) was from warm temperate latitudes $\left(36^{\circ} 28.40^{\prime} \mathrm{S}\right)$ and the other section (Site 593) was from cooler, southern temperate latitudes $\left(40^{\circ} 30.47^{\prime} \mathrm{S}\right)$. The sections were relatively continuous (recovery $>70 \%$ ) and mechanically undisturbed by the $\mathrm{XCB}$ technique. The sites were at shallow paleodepths $(\sim 1000 \mathrm{~m})$ and are rich in calcareous microfossils. By collecting these temperate sections, we could study the development of late Paleogene latitudinal temperature gradients in conjunction with another site (Site 277) presently located in subantarctic latitudes $\left(52^{\circ} 13.43^{\prime} \mathrm{S}\right)$. Site 277 has been used as the standard of reference for high-latitude stable-isotope development (Shackleton and Kennett, 1975). This isotope record was based on analyses of mixed benthic genera and mixed planktonic species of foraminifers. The analysis of mixed planktonic taxa resulted in a generalized isotopic signal because of the averaging effect of combining taxa living at different levels of the water column. The mixture of different benthic genera adds the species-specific disequilibrium value of each taxa to the resulting signal, again producing an averaged record. The late Eocene-early Oligocene portion of Site 277 was reanalyzed by Keigwin (1980) using monospecific samples of Globigerina angiporoides and Oridorsalis umbonatus. In order to

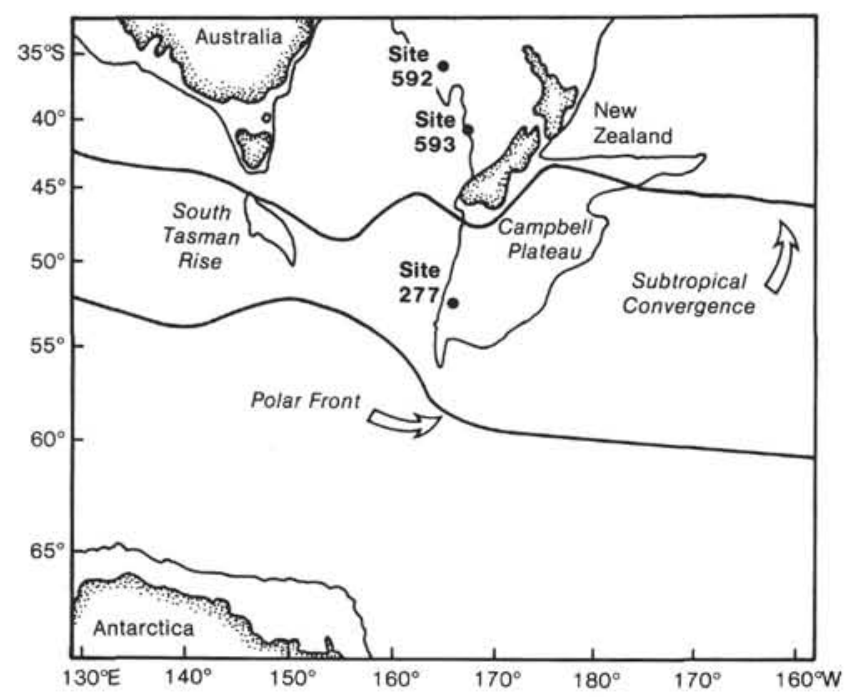

Figure 1. Location map of DSDP Sites 592, 593 and 277. Position of Subtropical Convergence and Polar Front from Gordon (1972); $2000-\mathrm{m}$ isobath is shown. compare this high-latitude section with the two temperate Leg 90 sites, we analyzed the remainder of Site 277 using monospecific samples.

\section{METHODS}

Samples $\left(5 \mathrm{~cm}^{3}\right)$ were dried in a $50^{\circ} \mathrm{C}$ oven and weighed after saving a small subsample for calcareous nannofossil analysis. The bulk sample was disaggregated in hog Calgon solution and washed over a $63-\mu \mathrm{m}$ sieve. The $<63-\mu \mathrm{m}$ residue was retained and centrifuged for future analysis. The $>63-\mu \mathrm{m}$ residue was trapped on filter paper, dried at $50^{\circ} \mathrm{C}$, and weighed. The samples were then dry sieved $(>250 \mu \mathrm{m})$ and the foraminifer species Globigerina angiporoides and Oridorsalis umbonatus were picked for analysis. These species were chosen for their common occurrence throughout the sections. G. angiporoides is believed to have inhabited near-surface waters (Keigwin, 1980), whereas $O$. umbonatus is a distinctive, long-ranging benthic form found to deviate consistently from both $\delta^{18} \mathrm{O}$ and $\delta^{13} \mathrm{C}$ equilibria (Graham et al., 1981). These monospecific subsamples were sonicated in methanol to remove adhering particles, dried at $50^{\circ} \mathrm{C}$, and loaded into stainless steel "boats." The loaded boats were roasted in vacuo at $350^{\circ} \mathrm{C}$ for 60 min., allowed to cool, and placed into the sampling arm for stable-isotope analysis.

Each analytical session on the mass spectrometer was preceded and followed by an analysis of the powdered laboratory standard B-1, which has an analytical precision of less than $\pm 0.10 \%$ for both $\delta^{18} \mathrm{O}$ and $\delta^{13} \mathrm{C}$. The procedure followed that of Keigwin (1980) with dissolution in phosphoric acid at $50^{\circ} \mathrm{C}$, followed by three serial distillations to obtain pure carbon dioxide gas. Analyses were performed on the University of Rhode Island (URI) VG 602D mass spectrometer. Recent recalibration of the URI B-1 standard has resulted in an adjustment of our oxygen-isotope values by $+0.29 \%$ when corrected to Pee Dee belemnite (PDB); the carbon values do not require adjustment. This will affect all analyses of carbonate material published by the URI laboratory between 1980 and September, 1984. The URI reference gas is lighter by $0.59 \% 0$ with respect to PDB for $\delta^{18} \mathrm{O}$, and heavier by $1.22 \%$ than PDB for $\delta^{13} \mathrm{C}$ (see Appendix).

Sample reproducibility based upon one sigma of the means of 30 sets of $G$. angiporoides and 17 sets of $O$. umbonatus duplicates was \pm $0.09 \%$ for planktonic $\delta^{18} \mathrm{O}$ and $\delta^{13} \mathrm{C} ; 0.08 \%$ for benthic $\delta^{18} \mathrm{O}$, and $0.13 \%$ for benthic $\delta^{13} \mathrm{C}$. Isotopic results were corrected mathematically for tailing effects as detailed in Craig (1957; Table 1). Samples were checked for possible recrystallization by examination under the scanning electron microscope. Strontium to calcium ratios and strontium-isotope analyses of planktonic foraminifers from Site 593 has also demonstrated the pristine nature of these samples (Hess and Schilling, this volume).

Biostratigraphic zonal nomenclature is after Martini (this volume) and Jenkins and Srinivasan (this volume). Ages are assigned to faunal datum planes after Berggren et al. (in press). For purposes of discussion in this chapter, the Oligocene is divided into three time intervals: early (37.5-33 Ma); middle (33-28 Ma) and late (28-23.5 Ma).

\section{RESULTS OF ISOTOPIC ANALYSES}

\section{Site 277}

The oxygen-isotope record from Site 277 , at subantarctic latitudes (present position $52^{\circ} 13.43^{\prime} \mathrm{S}$; $166^{\circ} 11.48^{\prime} \mathrm{E}, 1214 \mathrm{~m}$ water depth), was used as the basis for the Eocene-Oligocene portion of the standard Cenozoic high-latitude temperature curve (Shackleton and Kennett, 1975) and has subsequently been included in several global syntheses (e.g., Savin, 1977; Savin and Yeh, 1981; Shackleton et al., 1984). The first step in this study was to reanalyze this important section using monospecific samples and use the resultant curve as a basis of comparison with the record at Sites 592 and 593.

In their analysis of Site 277, Shackleton and Kennett (1975) found relatively constant late Eocene oxygen-iso- 
Table 1. Isotopic data from Holes $277,592,593$, and 593A corrected to PDB.

\begin{tabular}{|c|c|c|c|c|c|}
\hline \multirow[b]{2}{*}{ Sample } & \multirow[b]{2}{*}{ Depth } & \multicolumn{2}{|c|}{$\begin{array}{l}\text { Globigerina } \\
\text { angiporoides }\end{array}$} & \multicolumn{2}{|c|}{$\begin{array}{l}\text { Oridorsalis } \\
\text { umbonatus }\end{array}$} \\
\hline & & $\delta^{18} \mathrm{O}$ & $\delta^{13} \mathrm{C}$ & $\delta^{18} \mathrm{O}$ & $\delta^{13} \mathrm{C}$ \\
\hline \multicolumn{6}{|l|}{ Hole 277} \\
\hline $2-2,140-142$ & 9.9 & 1.37 & 1.06 & 1.72 & 0.58 \\
\hline $2-5,140-142$ & 14.4 & 1.29 & 1.10 & 1.77 & 0.41 \\
\hline $3-2,139-140$ & 19.4 & 1.35 & 0.74 & 1.91 & -0.41 \\
\hline $3-5,140-142$ & 23.9 & 1.65 & 0.94 & 1.72 & -0.52 \\
\hline $4-5,140-142$ & 33.4 & 1.17 & 0.86 & 1.66 & 0.36 \\
\hline $4-5,140-142$ & 33.4 & 1.25 & 0.96 & - & \\
\hline $5-2,140-142$ & 38.4 & 1.41 & 0.86 & 1.64 & 0.61 \\
\hline $5-5,140-142$ & 42.9 & 1.08 & 0.39 & 2.05 & 0.03 \\
\hline $6-2,140-142$ & 46.9 & 1.19 & 1.16 & 1.92 & -0.21 \\
\hline $6-5,140-142$ & 52.4 & 1.04 & 0.49 & 1.36 & -0.36 \\
\hline $7-2,140-142$ & 57.4 & 1.20 & 1.29 & 1.64 & -0.15 \\
\hline $7-2,140-142$ & 57.4 & 0.81 & 0.76 & - & - \\
\hline $7-5,140-142$ & 61.9 & 0.96 & 1.14 & 1.46 & 0.39 \\
\hline $8-2,140-142$ & 66.9 & 0.87 & 0.93 & 1.00 & 0.11 \\
\hline $8-2,140-142$ & 66.9 & 1.03 & 1.09 & 1.30 & 0.14 \\
\hline $8-5,140-142$ & 71.4 & 1.07 & 1.15 & 1.77 & 0.08 \\
\hline $8-5,140-142$ & 71.4 & 1.20 & 1.20 & 2.01 & 0.74 \\
\hline $8-5,140-142$ & 71.4 & 1.17 & 0.98 & - & - \\
\hline $9-2,140-142$ & 76.4 & 1.62 & 0.83 & 1.97 & -0.17 \\
\hline $9-5,140-142$ & 80.9 & 1.04 & 1.05 & 1.48 & -0.71 \\
\hline $10-2,139-140$ & 85.9 & 1.04 & 1.07 & 1.72 & -0.42 \\
\hline $10-5,140-142$ & 90.4 & 1.08 & 1.20 & 1.84 & -0.23 \\
\hline $10-5,140-142$ & 90.4 & 1.17 & 1.04 & - & - \\
\hline $11-2,140-142$ & 95.4 & 0.96 & 1.05 & 1.51 & 0.01 \\
\hline $11-2,140-142$ & 95.4 & 1.16 & 0.89 & 1.59 & -0.04 \\
\hline $11-2,140-142$ & 95.4 & 0.98 & 0.78 & - & - \\
\hline $11-5,140-142$ & 99.9 & 0.86 & 1.04 & 1.03 & 0.34 \\
\hline $11-5,140-142$ & 99.9 & 0.95 & 0.77 & 1.38 & -0.13 \\
\hline $12-2,140-142$ & 104.9 & - & - & 1.75 & -0.13 \\
\hline $12-5,140-142$ & 109.4 & 1.07 & 1.18 & 1.37 & 0.30 \\
\hline $12-5,140-142$ & 109.4 & 1.06 & 1.08 & - & - \\
\hline $13-2,140-142$ & 114.4 & 0.78 & 1.04 & 1.12 & 0.24 \\
\hline $13-5,140-142$ & 119.4 & 0.68 & 1.23 & 1.35 & 0.19 \\
\hline $14-2,140-142$ & 123.9 & 1.13 & 1.56 & 1.32 & 0.54 \\
\hline $14-2,140-142$ & 123.9 & 1.01 & 0.31 & - & - \\
\hline $14-5,140-142$ & 128.3 & 1.18 & 1.02 & 1.69 & -0.26 \\
\hline $15-2,140-142$ & 133.4 & 0.80 & 1.52 & 1.33 & -0.21 \\
\hline $15-2,140-142$ & 133.4 & - & - & 1.48 & 0.39 \\
\hline $15-5,141-142$ & 137.9 & 0.68 & 0.99 & 1.62 & 0.18 \\
\hline $16-2,140-142$ & 142.9 & 0.79 & 1.37 & 1.44 & 0.19 \\
\hline $17-2,140-142$ & 152.4 & 0.85 & 0.94 & 1.44 & 0.61 \\
\hline $18-2,140-142$ & 161.9 & - & - & 1.52 & -0.04 \\
\hline $19-2,136-137$ & 171.4 & 1.14 & 1.54 & 1.81 & 0.13 \\
\hline $19-2,136-137$ & 171.4 & 1.11 & 1.43 & - & - \\
\hline $20-5,140-142$ & 185.4 & 0.65 & 1.25 & 0.80 & -0.17 \\
\hline $20-6,142-143$ & 186.9 & -0.05 & 0.95 & 0.95 & -0.33 \\
\hline $20-6,142-143$ & 186.9 & 0.23 & 1.03 & - & - \\
\hline $21-1,140-141$ & 188.9 & 0.76 & 1.21 & 0.90 & -0.22 \\
\hline $21-1,140-141$ & 188.9 & 0.03 & 1.04 & - & - \\
\hline $21-2,140-142$ & 190.4 & 0.26 & 1.14 & 0.90 & -0.18 \\
\hline $22-1,135-136$ & 198.3 & 0.24 & 1.40 & 0.88 & 0.20 \\
\hline $22-2,139-140$ & 199.9 & 0.39 & 1.40 & 0.95 & 0.14 \\
\hline $22-3,140-142$ & 201.4 & 0.01 & 1.70 & 0.76 & 0.37 \\
\hline
\end{tabular}

Hole 592

$\begin{array}{llllll}33-3,35-36 & 305.46 & 0.28 & 1.12 & - & - \\ 33-4,35-36 & 306.96 & 0.73 & 1.15 & 1.24 & 0.54 \\ 33-5,35-36 & 308.46 & 0.70 & 1.23 & 1.20 & 0.46 \\ 34-1,35-36 & 312.06 & 0.77 & 1.29 & 1.29 & 0.47 \\ 34-1,35-36 & 312.06 & - & - & 1.24 & 0.31 \\ 34-2,35-36 & 313.56 & 0.74 & 1.25 & 1.28 & 0.37 \\ 34-3,35-36 & 315.06 & 0.76 & 1.27 & 1.29 & 0.57 \\ 34-4,35-36 & 316.56 & 0.77 & 1.42 & 1.31 & 0.75 \\ 34-5,35-36 & 318.06 & 0.79 & 1.58 & 1.40 & 0.84 \\ 34-5,35-36 & 318.06 & - & - & 1.26 & 0.51 \\ 34-6,35-36 & 319.56 & 0.86 & 1.61 & 1.46 & 0.69 \\ 35-1,35-36 & 321.66 & 0.88 & 1.77 & 1.44 & 0.70 \\ 35-1,35-36 & 321.66 & 0.90 & 1.71 & - & - \\ 35-2,35-36 & 323.16 & 0.87 & 1.51 & 1.46 & 0.45 \\ 35-3,35-36 & 324.66 & 0.58 & 1.63 & 1.03 & 0.38 \\ 35-4,35-36 & 326.16 & 0.54 & 1.38 & 1.09 & 0.67\end{array}$

Table 1. (Continued).

\begin{tabular}{|c|c|c|c|c|c|}
\hline \multirow[b]{2}{*}{ Sample } & \multirow[b]{2}{*}{ Depth } & \multicolumn{2}{|c|}{$\begin{array}{c}\text { Globigerina } \\
\text { angiporoides }\end{array}$} & \multicolumn{2}{|c|}{$\begin{array}{l}\text { Oridorsalis } \\
\text { umbonatus }\end{array}$} \\
\hline & & $\delta^{18} \mathrm{O}$ & ${ }_{\delta^{13}} \mathrm{C}$ & $\delta^{18} \mathrm{O}$ & ${ }_{\delta^{13}} \mathrm{C}$ \\
\hline \multicolumn{6}{|l|}{ Hole 592 (cont.) } \\
\hline $35-4,35-36$ & 326.16 & - & - & 1.08 & 0.17 \\
\hline $35-5,35-36$ & 327.66 & 0.30 & 1.44 & 0.95 & 0.07 \\
\hline $35-6,35-36$ & 329.16 & 0.35 & 1.26 & 1.09 & 0.10 \\
\hline $36-1,35-36$ & 331.26 & 0.59 & 1.43 & 1.09 & 0.18 \\
\hline $36-1,35-36$ & 331.26 & 0.14 & 1.32 & - & - \\
\hline $36-1,62-63$ & 31.53 & 0.32 & 1.31 & 0.91 & 0.16 \\
\hline $36-1,92-93$ & 331.83 & 0.33 & 1.29 & 1.05 & 0.25 \\
\hline $36-1,120-121$ & 332.15 & 0.47 & 1.37 & 1.04 & 0.12 \\
\hline $36-1,144-145$ & 332.35 & 0.31 & 1.16 & 1.03 & 0.12 \\
\hline $36-1,144-145$ & 332.35 & 0.19 & 1.02 & - & - \\
\hline $36-2,35-36$ & 332.76 & 0.28 & 1.12 & 0.98 & 0.03 \\
\hline $36-2,63-64$ & 333.04 & 0.58 & 1.09 & 1.09 & -0.09 \\
\hline $36-2,86-87$ & 333.27 & 0.49 & 1.13 & 1.14 & 0.21 \\
\hline $36-2,119-120$ & 333.60 & 0.33 & 1.18 & 1.19 & -0.19 \\
\hline $36-2,146-148$ & 333.87 & 0.37 & 0.95 & 1.04 & 0.01 \\
\hline $36-3,28-29$ & 334.19 & 0.35 & 0.91 & 0.87 & -0.27 \\
\hline $36-3,35-36$ & 334.26 & 0.43 & 1.05 & 0.98 & -0.17 \\
\hline $36-3,47-48$ & 334.38 & 0.10 & 0.85 & 0.72 & -0.39 \\
\hline $36-3,47-48$ & 334.38 & 0.15 & 0.94 & - & - \\
\hline $36-3,96-97$ & 334.87 & 0.11 & 1.20 & 0.77 & 0.20 \\
\hline $36-3,146-147$ & 335.47 & 0.43 & 1.28 & 0.87 & 0.35 \\
\hline $36-3,146-147$ & 335.47 & 0.07 & 1.12 & - & - \\
\hline $37-1,60-61$ & 341.11 & -0.16 & 1.09 & 0.57 & 0.15 \\
\hline $37-1,60-61$ & 341.11 & 0.11 & 1.13 & - & - \\
\hline $37-1,120-121$ & 341.71 & 0.02 & 1.00 & 0.30 & -0.08 \\
\hline $37-1,141-142$ & 341.92 & 0.25 & 1.21 & 0.66 & 0.09 \\
\hline $37-2,32-33$ & 342.33 & 0.22 & 1.11 & 0.48 & -0.04 \\
\hline $37-2,62-63$ & 342.63 & 0.11 & 1.14 & 0.57 & 0.17 \\
\hline $37-2,62-63$ & 342.63 & 0.11 & 0.99 & - & - \\
\hline $37-2,92-93$ & 342.93 & 0.34 & 1.16 & 0.66 & -0.10 \\
\hline $37-2,122-123$ & 343.23 & 0.18 & 1.22 & 0.58 & 0.09 \\
\hline $37-2,142-143$ & 343.43 & 0.00 & 1.29 & 0.61 & 0.09 \\
\hline $37-3,20-21$ & 343.71 & 0.18 & 1.30 & 1.03 & 0.58 \\
\hline $37-3,20-21$ & 343.71 & - & $\overline{-1}$ & 0.78 & 0.34 \\
\hline $37-3,50-51$ & 344.01 & -0.28 & 1.24 & 0.72 & 0.18 \\
\hline $37-3,70-71$ & 344.21 & -0.22 & 1.31 & 0.71 & 0.20 \\
\hline $37-3,93-94$ & 344.44 & 0.16 & 1.30 & 0.68 & 0.03 \\
\hline $37-3,116-117$ & 344.67 & -0.05 & 1.30 & 0.70 & 0.11 \\
\hline $37-4,32-33$ & 345.33 & 0.00 & 1.21 & 1.33 & 0.15 \\
\hline $37-4,32-33$ & 345.33 & - & - & 0.90 & 0.09 \\
\hline $37-4,64-65$ & 345.65 & 0.23 & 1.28 & 0.68 & 0.20 \\
\hline $37-4,64-65$ & 45.65 & - & - & 0.69 & 0.29 \\
\hline $38-1,35-36$ & 50.46 & 0.27 & 1.43 & 0.60 & 0.33 \\
\hline $38-2,35-36$ & 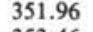 & 0.18 & 1.50 & 0.70 & 0.33 \\
\hline $38-3,35-36$ & 3.46 & 19 & 1.68 & 0.68 & 0.43 \\
\hline $38-5,35-36$ & 36.46 & -0.01 & 1.63 & 0.60 & 0.45 \\
\hline $38-6,35-36$ & 7796 & -0.02 & 1.71 & 0.59 & 0.56 \\
\hline $39-1,35-36$ & 60.06 & -0.08 & 1.81 & 0.37 & 0.85 \\
\hline $39-2,35-36$ & 36156 & -0.17 & 1.44 & 0.50 & 0.44 \\
\hline $39-3,35-36$ & 63.06 & 0.01 & 1.68 & 0.59 & 0.71 \\
\hline $40-1,35-36$ & 369.66 & 0.00 & 1.50 & 0.27 & 0.31 \\
\hline $40-3,35-36$ & 372.66 & 0.08 & 1.40 & 0.62 & 0.22 \\
\hline $40-4,36-38$ & 74.17 & 0.06 & 1.31 & 0.59 & 0.10 \\
\hline $40-5,36-37$ & 5.67 & 0.00 & 1.15 & 0.65 & -0.12 \\
\hline $41-1,35-37$ & 19.26 & -0.05 & 1.3 & 0.58 & 0.18 \\
\hline $41-3,35-37$ & 2.26 & 0.24 & 1.27 & 0.63 & -0.14 \\
\hline $41-4,35-37$ & 13 & & 1.34 & 0.73 & 0.12 \\
\hline $41-5,35-37$ & 6 & 0.30 & 1.22 & 0.78 & -0.11 \\
\hline $41-6,35-37$ & 386.76 & 0.15 & 1.26 & 0.65 & -0.11 \\
\hline \multicolumn{6}{|l|}{ Hole 593} \\
\hline & 4 & & 1.1 & 12 & 0.59 \\
\hline 5 & 0.76 & & 1.06 & 1.10 & 0.09 \\
\hline 5 & & & 1.67 & 1.35 & 0.82 \\
\hline $35-37$ & 1 & & 0.90 & 1.33 & 0.00 \\
\hline $1,35-3$ & 5 & 0.56 & 0.99 & 1.01 & 0.29 \\
\hline $2,35-37$ & 486.96 & 0.23 & 0.74 & 0.69 & -0.45 \\
\hline $25-3$ & & 0.63 & 1.06 & 1.16 & -0.15 \\
\hline 2 & & & 0.75 & 1.07 & -0.34 \\
\hline $53-2,35-37$ & 496.56 & 0.73 & 1.12 & 1.47 & -0.07 \\
\hline $53-3,35-37$ & 498.06 & 0.67 & 1.40 & 1.32 & -0.08 \\
\hline
\end{tabular}


Table 1. (Continued).

\begin{tabular}{|c|c|c|c|c|c|}
\hline \multirow[b]{2}{*}{ Sample } & \multirow[b]{2}{*}{ Depth } & \multicolumn{2}{|c|}{$\begin{array}{c}\text { Globigerina } \\
\text { angiporoides }\end{array}$} & \multicolumn{2}{|c|}{$\begin{array}{l}\text { Oridorsalis } \\
\text { umbonatus }\end{array}$} \\
\hline & & $\delta^{18} \mathrm{O}$ & $\delta^{13} \mathrm{C}$ & ${ }_{\delta^{18} \mathrm{O}}$ & ${ }_{\delta^{13} \mathrm{C}}^{13}$ \\
\hline \multicolumn{6}{|l|}{ Hole 593 (cont.) } \\
\hline $53-3,35-37$ & 498.06 & 0.46 & 1.18 & 1.33 & -0.32 \\
\hline $53-4,35-37$ & 499.56 & 0.84 & 1.07 & 1.49 & -0.09 \\
\hline $54-1,35-37$ & 504.66 & 0.87 & 0.96 & 1.46 & -0.05 \\
\hline $54-1,35-37$ & 504.66 & 0.82 & 1.08 & - & - \\
\hline $54-2,35-37$ & 506.16 & 0.74 & 1.08 & 1.46 & -0.02 \\
\hline $54-3,35-37$ & 507.60 & 0.92 & 1.23 & 1.46 & 0.21 \\
\hline $54-3,35-37$ & 507.60 & 0.95 & 1.43 & - & - \\
\hline $54-4,35-37$ & 509.16 & 0.76 & 1.13 & 1.49 & 0.00 \\
\hline $54-5,35-37$ & 510.66 & 0.39 & 0.89 & 1.05 & -0.16 \\
\hline $55-1,35-37$ & 514.26 & 0.62 & 1.13 & 1.32 & 0.02 \\
\hline $55-2,35-37$ & 515.76 & 0.36 & 1.19 & 1.15 & 0.15 \\
\hline $55-2,35-37$ & 515.76 & 0.49 & 1.52 & 1.03 & 0.28 \\
\hline $55-4,35-37$ & 518.76 & 0.51 & 1.57 & 1.39 & 0.41 \\
\hline $55-4,35-37$ & 518.76 & 0.59 & 1.58 & 1.15 & 0.77 \\
\hline $55-5,35-37$ & 520.26 & 0.49 & 1.21 & 1.06 & 0.24 \\
\hline $55-5,35-37$ & 520.26 & - & - & 1.15 & 0.14 \\
\hline $55-6,35-37$ & 521.76 & 0.38 & 1.18 & 0.89 & -0.04 \\
\hline $56-1,35-37$ & 523.86 & 0.33 & 1.03 & 1.03 & 0.23 \\
\hline $56-2,35-37$ & 525.36 & 0.44 & 0.90 & 1.13 & 0.17 \\
\hline $56-2,35-37$ & 525.36 & 0.39 & 1.11 & - & - \\
\hline $56-3,35-37$ & 526.86 & 0.59 & 0.97 & 1.08 & -0.02 \\
\hline $56-4,35-37$ & 528.36 & 0.50 & 1.06 & 1.08 & 0.28 \\
\hline $56-4,35-37$ & 528.36 & - & - & 1.15 & 0.46 \\
\hline $56-5,35-37$ & 529.86 & 0.92 & 1.20 & 1.00 & 0.29 \\
\hline $56-5,35-37$ & 529.86 & 0.60 & 1.14 & - & - \\
\hline $56-6,35-37$ & 531.36 & 0.45 & 0.98 & 1.38 & 0.15 \\
\hline $57-1,35-37$ & 533.46 & 0.63 & 1.14 & 0.93 & 0.13 \\
\hline $57-2,35-37$ & 534.96 & 0.71 & 1.34 & 1.12 & 0.49 \\
\hline $57-3,35-37$ & 536.46 & 0.64 & 1.26 & 1.36 & 0.60 \\
\hline $57-4,35-37$ & 537.96 & 0.71 & 1.38 & 1.37 & 0.28 \\
\hline $57-4,35-37$ & 537.96 & 0.45 & 1.59 & - & - \\
\hline $57-5,35-37$ & 539.46 & 0.98 & 1.38 & 1.16 & 0.22 \\
\hline $57-5,35-37$ & 539.46 & 0.69 & 1.44 & - & - \\
\hline $57-6,35-37$ & 540.96 & 0.51 & 1.64 & 1.33 & 0.76 \\
\hline $58-1,35-37$ & 543.06 & 0.16 & 1.14 & 0.86 & 0.01 \\
\hline $58-2,35-37$ & 544.56 & 0.37 & 0.79 & 0.67 & -0.14 \\
\hline $60-1,35-37$ & 562.26 & 0.04 & 0.81 & 0.68 & -0.37 \\
\hline $60-2,35-37$ & 563.76 & -0.02 & 0.78 & 0.54 & -0.26 \\
\hline $60-3,35-37$ & 565.26 & 0.19 & 0.74 & 0.75 & -0.66 \\
\hline $60-4,35-37$ & 566.76 & 0.10 & 0.46 & 0.85 & -0.66 \\
\hline $60-5,35-37$ & 568.26 & 0.08 & 0.98 & 0.65 & -0.35 \\
\hline $60-6,35-37$ & 569.76 & 0.17 & 0.95 & 0.68 & -0.13 \\
\hline
\end{tabular}

Hole 593A

$\begin{array}{lllllr}23-2,35-37 & 450.60 & 0.45 & 1.54 & 1.53 & -0.05 \\ 23-3,35-37 & 452.26 & 0.43 & 1.66 & 1.37 & 0.23 \\ 23-4,35-37 & 453.66 & 0.13 & 1.45 & 1.62 & -0.06 \\ 24-1,35-37 & 458.76 & 0.32 & 1.23 & 1.21 & 0.02 \\ 24-2,35-37 & 460.26 & 0.47 & 0.98 & 1.25 & 0.23 \\ 25-1,35-37 & 468.36 & 0.41 & 0.98 & 1.33 & -0.28 \\ 25-2,35-37 & 469.86 & 0.31 & 0.58 & 0.90 & -0.03 \\ 25-3,35-37 & 471.36 & 0.56 & 0.94 & 1.67 & 0.42 \\ 25-4,35-37 & 472.86 & 0.46 & 0.73 & 1.34 & 0.25 \\ 25-5,35-37 & 474.36 & 0.64 & 0.90 & 0.81 & 0.09 \\ 25-6,35-37 & 475.86 & 0.26 & 0.60 & 1.15 & 0.13 \\ 26-1,35-37 & 477.96 & 0.19 & 0.73 & 0.98 & -0.01 \\ 26-2,35-37 & 479.26 & 0.11 & 0.94 & 0.93 & -0.06 \\ 26-3,35-37 & 480.96 & 0.52 & 0.70 & 1.23 & -0.24 \\ 26-4,35-37 & 482.26 & 0.52 & 0.86 & 1.37 & -0.09 \\ 26-5,35-37 & 483.96 & 0.65 & 0.66 & 1.33 & 0.03 \\ 27-1,35-37 & 487.56 & 0.71 & 0.98 & 1.31 & 0.28 \\ 27-2,35-37 & 489.06 & 0.76 & 0.65 & 1.36 & -0.46 \\ 27-2,35-37 & 489.06 & - & - & 1.25 & -0.14 \\ 27-3,35-37 & 490.56 & 0.64 & 0.86 & 1.65 & 0.01 \\ 27-4,35-37 & 492.06 & 0.82 & 1.17 & 1.38 & -0.27 \\ 27-5,35-37 & 493.56 & 0.99 & 0.76 & 1.46 & -0.19 \\ 27-6,35-37 & 495.06 & 0.85 & 1.34 & 1.45 & -0.23\end{array}$

Note: - means not present. tope values followed by a rapid $1 \%$ enrichment in planktonic and benthic $\delta^{18} \mathrm{O}$ signals in close association with the Eocene/Oligocene boundary (Fig. 2). The Oligocene values were relatively constant, varying $\pm 0.2 \%$ and exhibiting no significant trends (Shackleton and Kennett, 1975).

Figure 3 shows our data together with that of Keigwin (1980), based on analyses of monospecific samples at Site 277 . These data show relatively constant late Eocene oxygen-isotope values followed by a sudden enrichment of $\sim 1.0 \%$ at the Eocene/Oligocene boundary. This isotopic shift is characterized by a slight "overshoot" followed by depletion to mean early Oligocene values, which were enriched about $0.6 \%$ relative to mean late Eocene values. Planktonic and benthic variations of $\pm 0.5 \%$ are generally parallel through the early and middle Oligocene, exhibiting a slight enrichment trend in $\delta^{18} \mathrm{O}$ for a total change of $0.5 \%$ from the early through the middle Oligocene.

The $\delta^{13} \mathrm{C}$ data presented by Shackleton and Kennett (1975) were not discussed and can not be interpreted here because of the mixed taxa analyzed. The major features of our monospecific $\delta^{13} \mathrm{C}$ record (Fig. 3) are (1) a $0.8 \%$ depletion in both planktonic and benthic values immediately prior to the Eocene/Oligocene boundary and (2) a $0.8 \%$ enrichment in the planktonic carbon record and a $1.0 \%$ enrichment in the benthic carbon record at the Eocene/Oligocene boundary in synchrony with the oxygen-isotope shift. The remaining planktonic carbon values are relatively constant, whereas the benthic record is characterized by at least three depletionenrichment cycles during the early to middle Oligocene. The record at this site lacks any parallelism between the planktonic and benthic carbon-isotope variations.

There are several differences between the results of our study and those of Shackleton and Kennett (1975). For the oxygen-isotope data these include larger amplitude variations, a distinct enrichment trend in the middle Oligocene, and the consistently depleted values seen in our monospecific data compared to the mixed species data. Our carbon-isotope records show much greater variability than those of Shackleton and Kennett (1975). These differences are almost certainly a result of the varying composition of the mixed samples analyzed by Shackleton and Kennett (1975).

\section{Site $\mathbf{5 9 3}$}

Hole 593, in southern temperate latitudes, was drilled at $40^{\circ} 30.47^{\prime} \mathrm{S} ; 167^{\circ} 47^{\prime} \mathrm{E}$ in $1068 \mathrm{~m}$ water depth. Core recovery was good (averaging $72 \%$ ) except for Core 51 spanning the Globigerina euapertura Zone, so a second hole (Hole 593A) was drilled to recover this section. The holes were correlated using faunal datums (Fig. 4). Holes 593 and 593A form a continuous section from the late Eocene through the earliest Miocene. The sediments are foraminifer-rich nannofossil oozes, except for a 16-m sequence of volcaniclastic turbidites, debris flows, and pyroclastic flows emplaced near the Eocene/Oligocene boundary. These flows can be traced on seismic profiles 


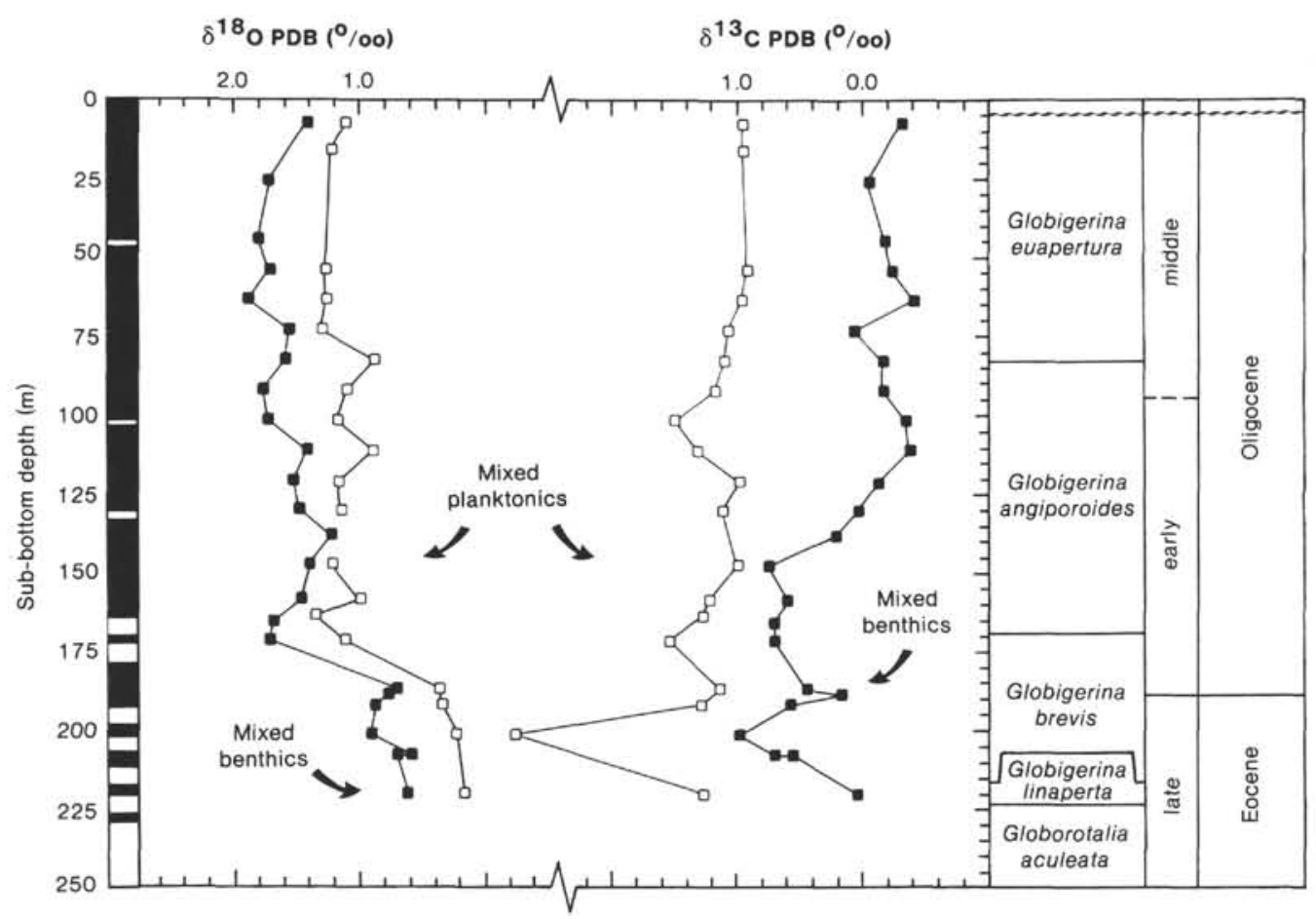

Figure 2. Oxygen- and carbon-isotope data from Shackleton and Kennett (1975) for DSDP Site 277. Foraminiferal stratigraphy after Jenkins (1975). Core recovery shown along left margin.

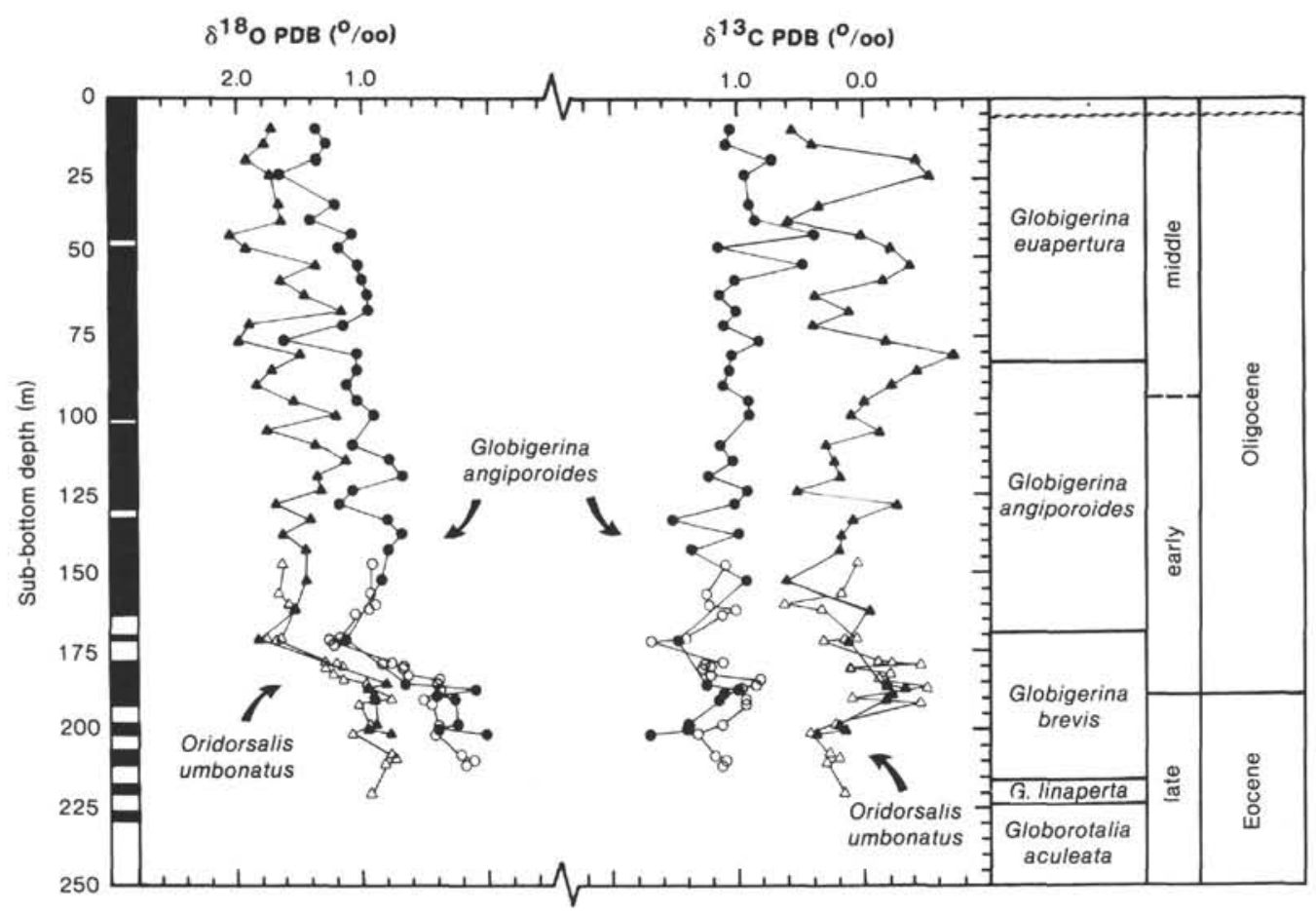

Figure 3. Oxygen- and carbon-isotope data from monospecific analyses of Site 277. Data from Keigwin (1980) indicated by open symbols. Stratigraphy after Jenkins (1975). Core recovery along left margin.

to the buried Lalitha Volcanic Pinnacle approximately $2 \mathrm{~km}$ from Site 593.

The $\delta^{18} \mathrm{O}$ isotope records for both planktonic and benthic foraminifers are remarkably parallel throughout the section, with a clear shift of $1.0 \%$ beginning in the late
Eocene, just below the volcanics, and reaching a maximum in early Oligocene Zones NP22/21. A gradual $0.5 \%$ depletion in early Oligocene $\delta^{18} \mathrm{O}$ values was followed by a stepped enrichment of $0.5 \%$ in the late-early Oligocene; the records gradually deplete $0.6 \%$ in the middle 


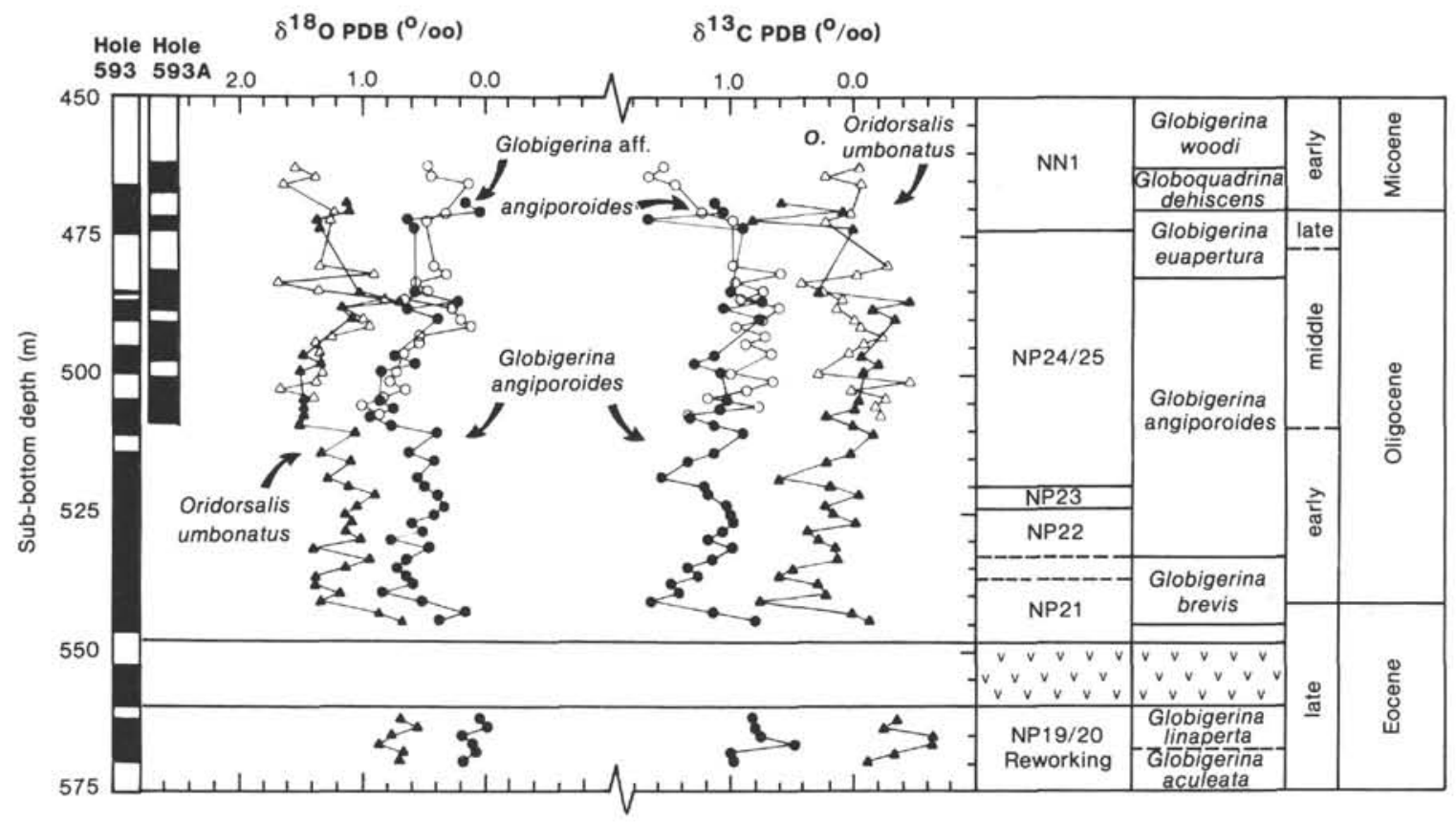

Figure 4. Oxygen- and carbon-isotope data from Holes 593 and 593A. Data from Hole 593A are indicated by open symbols. Calcareous nannoplankton stratigraphy after Martini (this volume). Planktonic foraminiferal stratigraphy after Jenkins and Srinivasan (this volume). Core recovery along left axis.

Oligocene. The late Oligocene benthic values exhibit a slight enrichment in contrast to continued depletion of the planktonic values.

The planktonic and benthic carbon-isotope records were very similar from the Eocene through the middle Oligocene, but diverged in the late Oligocene-early Miocene. A distinct $1.0 \% 0$ enrichment was synchronous with the Eocene/Oligocene boundary oxygen-isotope shift, after which the carbon-isotope curves exhibit a general trend toward depleted values. The records diverged in the late Oligocene ( $G$. euapertura Zone) when the planktonics showed enrichment, in contrast to a slight depletion in benthic $\delta^{13} \mathrm{C}$.

\section{Site $\mathbf{5 9 2}$}

Hole 592 was drilled at $36^{\circ} 28.40^{\prime} \mathrm{S} ; 165^{\circ} 26.53^{\prime} \mathrm{E}$ in $1098 \mathrm{~m}$ water depth, in the present northern temperate zone. A $90-\mathrm{m}$ section of upper Eocene through lower Oligocene sediments was recovered. This highly expanded section, with an average core recovery of $75 \%$, provided a detailed stable-isotope record.

Figure 5 exhibits the remarkable parallelism of planktonic and benthic oxygen- and carbon-isotope variation at this site (the offset between planktonic and benthic curves varies by only about $\pm 0.17 \% 0$ ). The oxygen-isotope record had relatively constant late Eocene values followed by a rapid depletion $(\sim 0.4 \%)$ and a distinct enrichment $(\sim 1.0 \%$ ) beginning at the base of Zone NP21, which is considered, on the basis of nannofossil biostratigraphy, to represent the Eocene/Oligocene boundary. This oxygen-isotope shift continued until the latest part of Zone NP21. The Eocene/Oligocene boundary, on the basis of planktonic foraminiferal biostratigraphy (last occurrence datum of Globigerinatheka index), occurred midway through this oxygen-isotope shift. Martini (this volume) estimates the time period between these two boundary definitions is $\sim 0.4 \mathrm{~m}$.y. The values then deplete slightly $(\sim 0.2 \%)$ from the peak associated with the NP21/NP22 boundary and have a depleting trend with little variation in the remaining early Oligocene.

The carbon-isotope record exhibits parallel trends between planktonic and benthic values similar to those seen in the oxygen-isotope data, both planktonic and benthic isotope records exhibit significant enrichments of $0.6-0.8 \%$ during the early part of the late Eocene Globigerina linaperta Zone. This was followed by $0.5 \%$ depletions in both records to the Eocene/Oligocene boundary (as recognized by the planktonic foraminiferal assemblages). The $\delta^{13} \mathrm{C}$ records were enriched by $\sim 1.0 \%$ in synchrony with the $\delta^{18} \mathrm{O}$ shift. These enrichments were followed by an apparent convergence of planktonic and benthic values in the middle Oligocene $G$. angiporoides Zone.

\section{CORRELATION OF ISOTOPIC CURVES}

The isotopic curves from the three sites were correlated using a combination of biostratigraphic datums as compiled in the Initial Reports of Legs 29 and 90 and isotopic events as detailed in Table 2 using the chronology of Berggren et al. (in press). The main problems encountered in this process were (1) the age of the hiatus at Site 277 and (2) the age of the material below the volcanic sequence at Site 593 . Site 277 is marked by a hiatus at $4.5 \mathrm{~m}$. Samples just below the hiatus contain Chiloguembelina cubensis (last occurrence datum of $30 \mathrm{Ma}$ : early/late Oligocene boundary; Berggren et al., in press), as well as Jenkinsina samwelli which exhibits a very short range in southwest Pacific Hole 282 and on 


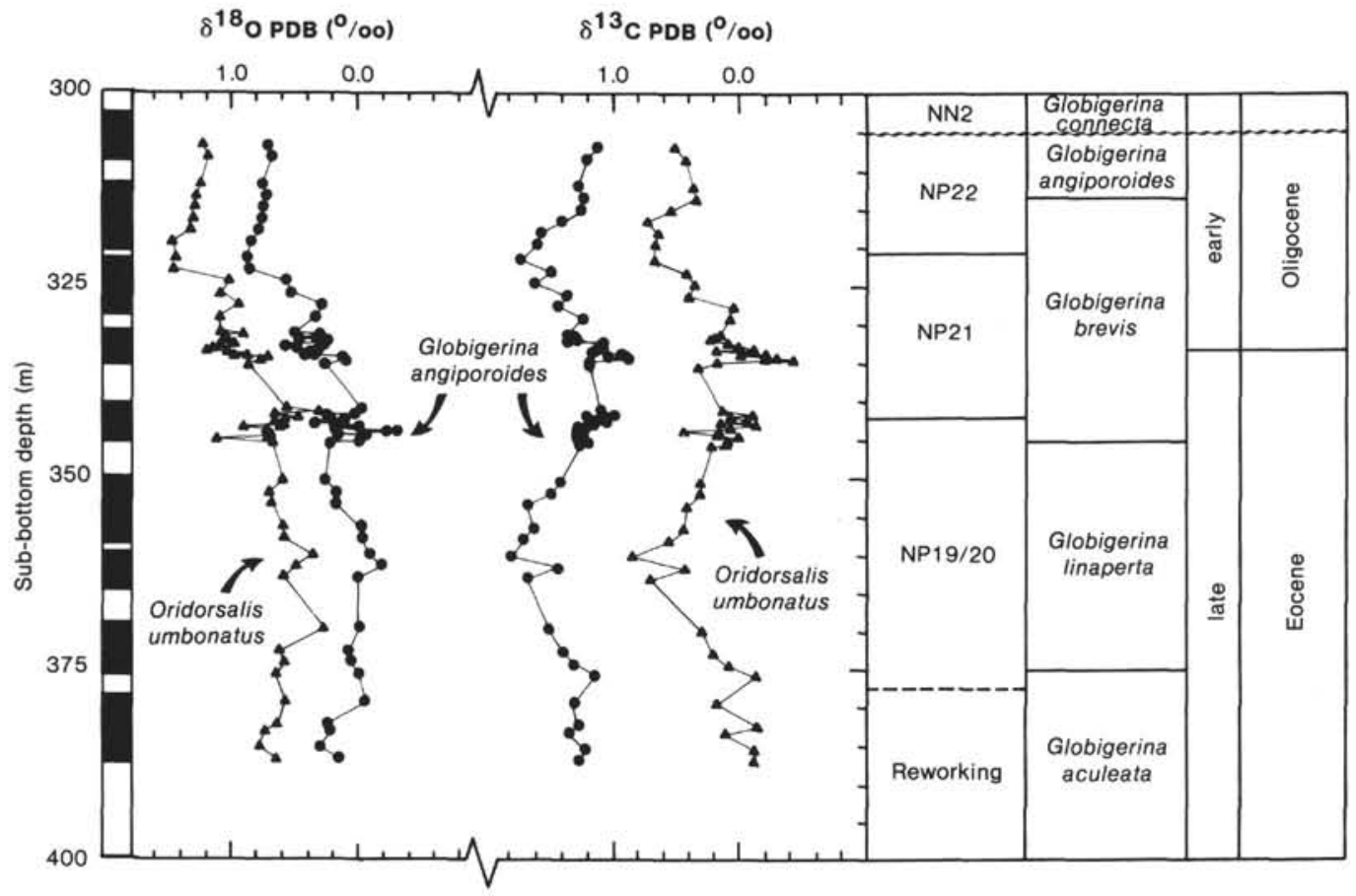

Figure 5. Oxygen- and carbon-isotope data from Site 592. Stratigraphy and recovery as in Figure 4.

Table 2. Chronostratigraphic datums used for correlation between the three sites.

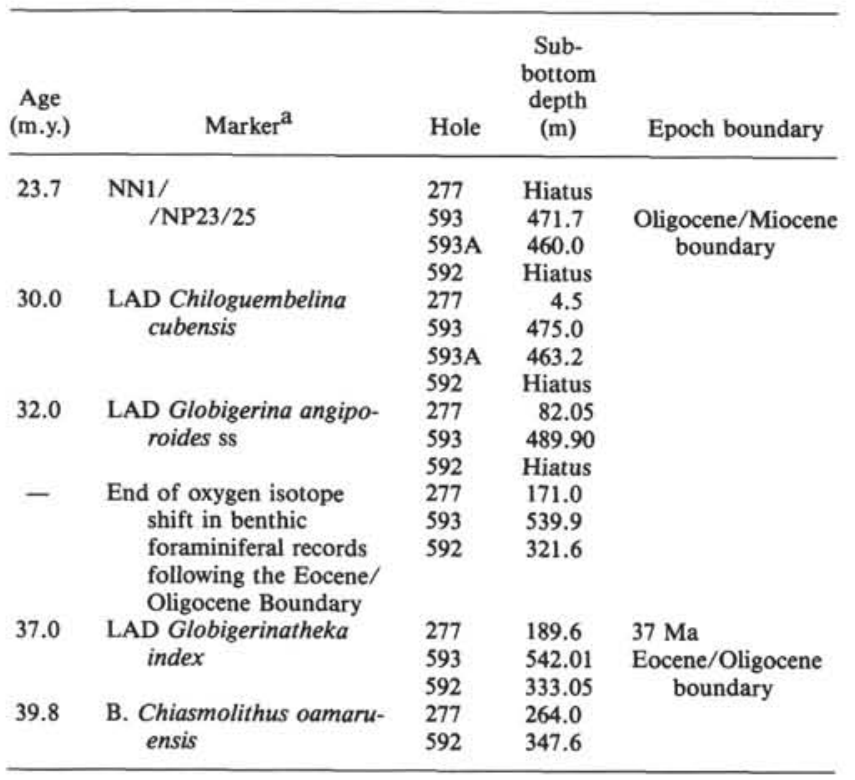

Note: Ages after Berggren et al. (in press).

${ }^{\mathrm{a}} \mathrm{LAD}=$ last appearance datum. $\mathrm{B} .=$ bottom.

the South Island, New Zealand, disappearing just below C. cubensis. The overlapping ranges of these two species at Site 277 suggest that the base of the hiatus is $\sim 31-32$ Ma (Jenkins, 1974).

At Site 593, changes in planktonic foraminifer assemblages used to recognize the Eocene/Oligocene boundary occur $3 \mathrm{~m}$ above the $16-\mathrm{m}$ volcanogenic sequence (Jenkins and Srinivasan, this volume). In contrast, the calcareous nannofossil forms that mark the upper Eocene occur immediately below and lower Oligocene forms occur immediately above the volcanogenics (Martini, this volume). Comparison of the isotopic curves of Site 277 with those of Sites 592 and 593 suggest that part of the sediment record laid down during the Eocene/Oligocene boundary oxygen-isotope shift at Site 593 has been removed, leaving the beginning and end of the shift in place. Based on this interpretation, Figure 6 shows the oxygen- and carbon-isotope data plotted against age.

\section{DISCUSSION}

The correlation of Holes 277, 593/593A, and 592 from the late Eocene through the middle Oligocene is shown is Figures $6 \mathrm{~A}$ and $6 \mathrm{~B}$. The oxygen-isotope records were divided into three stages for discussion: late Eocene to the Eocene/Oligocene boundary (41-37.5 Ma), the early Oligocene (37.5-33 Ma), and the middle Oligocene (33-28 Ma). The carbon-isotope records can be divided at $33 \mathrm{Ma}$ on the basis of the variation in the benthic isotope record.

The surface signals for all three sites overlap as do the intermediate records from the late Eocene through earliest Oligocene (Fig. 6A). This similarity between Site 277 on the Campbell Plateau to the south of New Zealand and Sites 592 and 593 in the Tasman Sea to the north of New Zealand suggests that the sites were influenced by the same surface and intermediate water masses and that no oceanographic front existed between the sites at that time. This conclusion is in agreement with the warm equable climates predicted for the Eocene with low pole-to-equator temperature gradients (Wolfe, 1971; Kennett, 1977; Frakes, 1979; Brass et al., 1982).

A change in thermal structure occurred in the earliest Oligocene ( $36.5-36 \mathrm{Ma})$ when Site 277 began to register consistently enriched ("cooler") isotopic values com- 

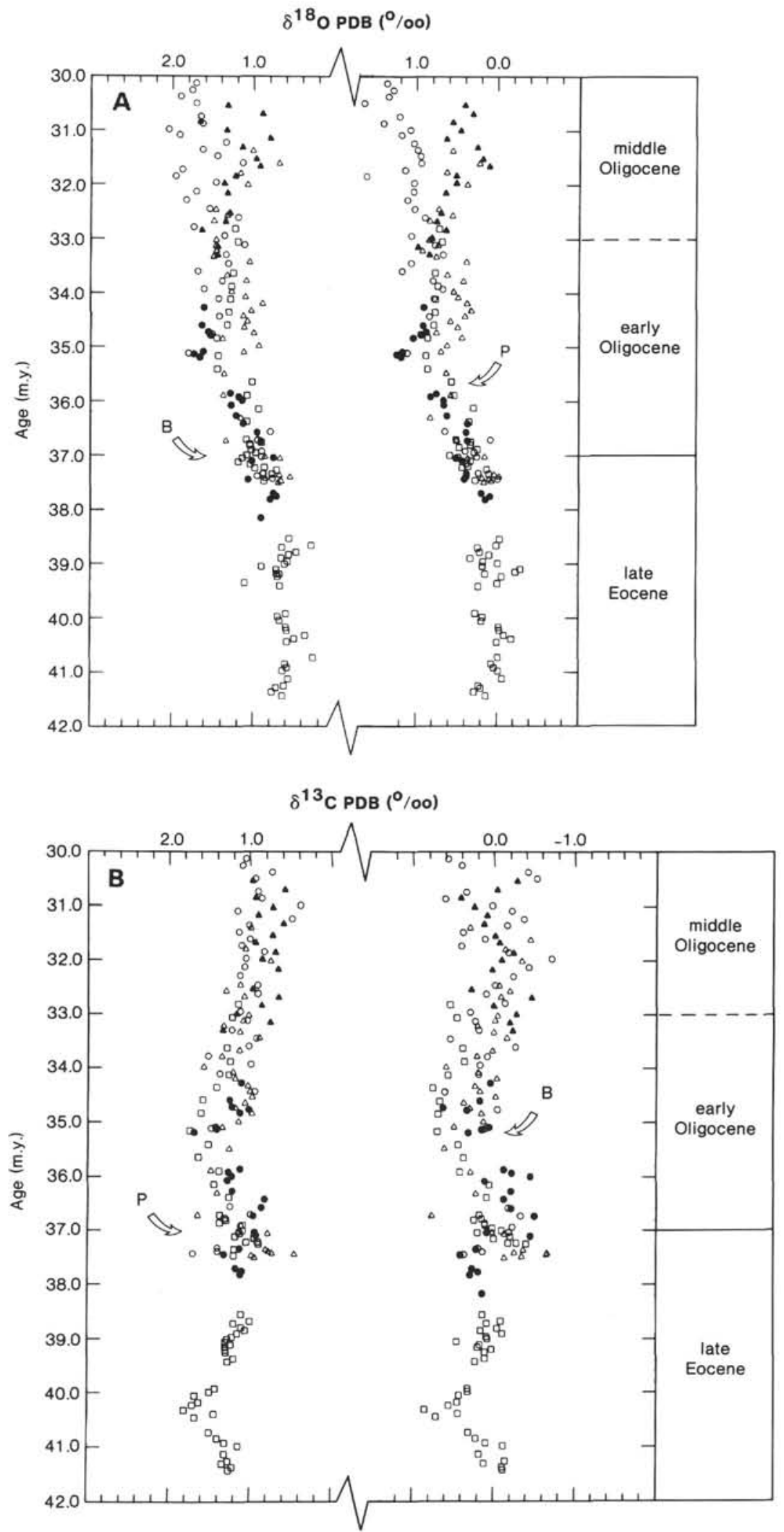

Figure 6. A. Plot of planktonic (P) and benthic (B) foraminiferal $\delta^{18} \mathrm{O}$ data in late Eocene to middle Oligocene sediments of Sites 277, 593, and 592. Age model given in Table 1. For purposes of discussion, the Oligocene is divided into: early (37-33 $\mathrm{Ma})$, middle (33-28 Ma), and late (28-23.5 Ma) intervals. Note increasing variability of data beginning at $\sim 35 \mathrm{Ma}$, reaching maximum offset in middle Oligocene. (O) Site 277, this study; (-) Site 277, Keigwin (1980); ( $\square$ ) Site 592, this study; $(\Delta)$ Site 593, this study; (A) Hole 593A, this study. B. Plot of $\delta^{13} \mathrm{C}$ data in late Eocene to middle Oligocene sediments of Sites 277,593 , and 592. Age model as described in Figure 6A. Note less scatter in planktonic data $(\mathrm{P})$ in contrast to greater variability of benthic data (B), most of which is due to fluctuations at Site 277 (line). Symbols as explained in Figure 6A. 
pared to Sites 592 and 593 to the north. This divergence gradually increased in the planktonic record during the early Oligocene (37.5-33 Ma), while the benthic records fluctuated, with Site 277 maintaining the more enriched values.

At $\sim 33 \mathrm{Ma}$, oxygen-isotope records at all three sites began to exhibit large variations $( \pm 0.4 \% 0)$, at least until $30.5 \mathrm{Ma}$. These oscillations overlay a divergence developing between the trend toward enrichment shown by Site 277 and the trend toward depletion exhibited by Site 593 (Fig. 7).

The carbon-isotope data are plotted in Figure 6B. The planktonic values form a narrow band with lowamplitude fluctuations $(<0.2 \% 0)$ about a value of $1.2 \%$ in the early Oligocene and $0.8 \%$ in the middle Oligocene. The benthic $\delta^{13} \mathrm{C}$ values were more variable, with the difference between sites increasing in the middle Oligocene ( $33 \mathrm{Ma})$, when Site 277 was characterized by large fluctuations, in contrast to the more constant values from Sites 592 and 593.

\section{TEMPERATURE ANALYSIS}

The oxygen-isotope data have been converted to paleotemperature values and plotted in Figure 8. Temperatures have been calculated assuming a lack of any significant ice accumulations in the polar regions during this time interval, as originally modeled by Shackleton and Kennett (1975) and by Savin et al. (1975) using the equation:

$$
\left.\mathrm{T}\left({ }^{\circ} \mathrm{C}\right)=16.9-4.38(\delta C-\delta W)+0.1[\delta C-\delta W)^{2}\right]
$$

where $\delta C=$ isotopic signal of carbonate deposited in equilibrium with seawater. Globigerina angiporoides is assumed to deposit in equilibrium with seawater. The Oridorsalis umbonatus data have been corrected to equilibrium calcite by a factor of $-0.42 \%$ in the temperature calculations (Graham et al., 1981). $\delta W=$ isotopic composition of global ocean. Shackleton and Kennett (1975) have assumed a constant oceanic composition of $-1.2 \% 0$ in an ice-free world.

This calculation results in minimum estimates of paleotemperatures, since the assumption of a constant $\delta W$ value throughout the late Paleogene is not correct. It is generally accepted that a major and permanent ice sheet accumulated on East Antarctica during the middle Miocene (15-13 Ma) (Shackleton and Kennett, 1975; Savin et al., 1981; Woodruff and Douglas, 1981; Kennett, 1982). However several workers have argued that there was an Antarctic ice sheet during certain intervals in the Oligocene (Miller and Fairbanks, 1983; Miller and Thomas, in press; Keigwin and Keller, 1984; Shackleton et al., 1984), or even during the entire Paleogene (Matthews and Poore, 1980; Poore and Matthews, 1984). These conclusions were based on isotopically derived bottom-water paleotemperatures cooler than those of the present oceans. These abnormal temperatures were explained by assuming a nonconstant $\delta W$ resulting from the accumulation of polar ice. Currently, little sedimentary evidence supports the existence of large accumulations of ice on Antarctica during the Paleogene. The marine record is poor in the circum-Antarctic region during the Oligocene. A glacial erosion surface on Antarctica has erased

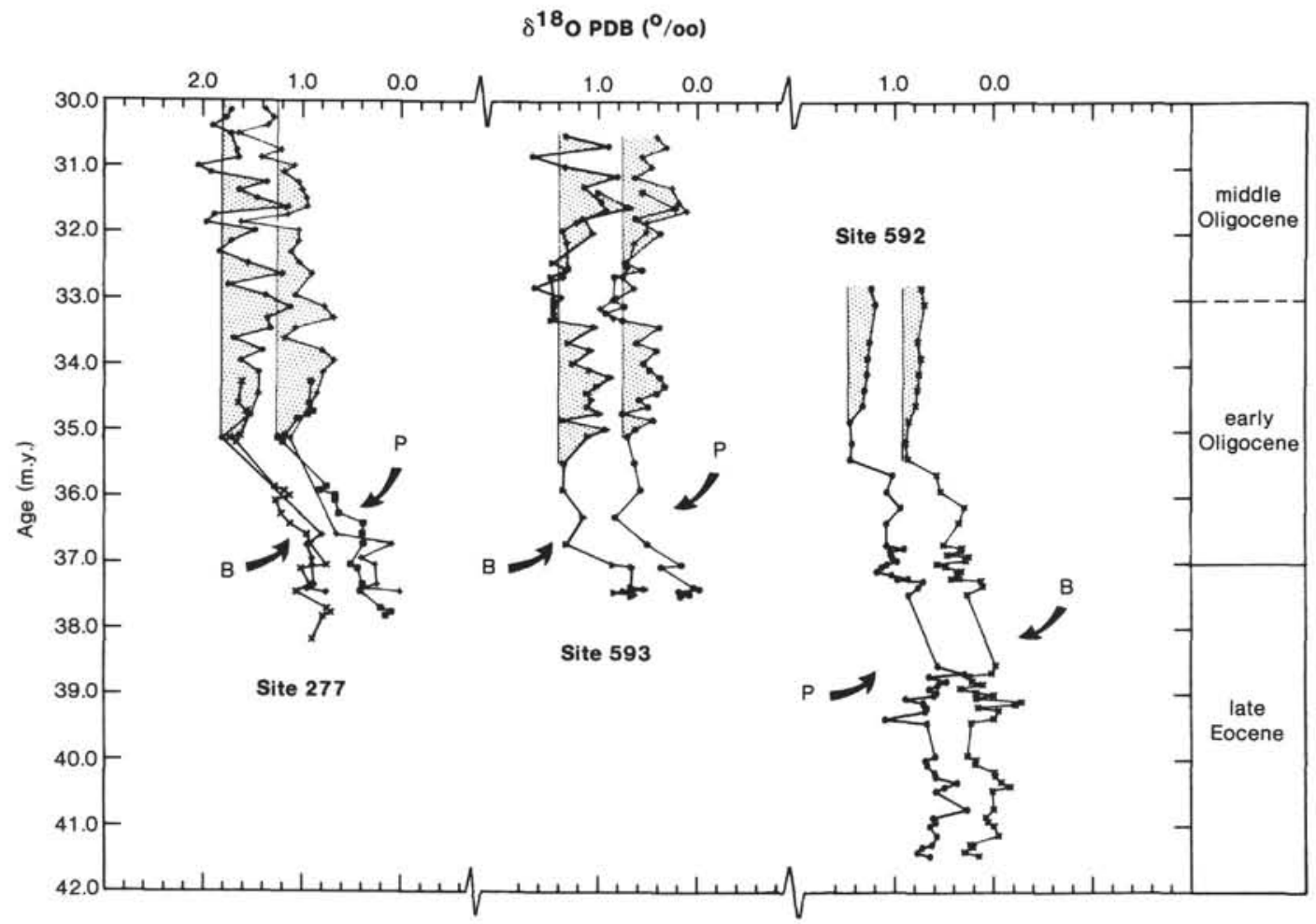

Figure 7. $\delta^{18} \mathrm{O}$ records from Sites 277,593 , and 592 plotted against age model described in Figure $6 \mathrm{~A}$. Stippled portions denote curves lighter than maximum enrichment attained at Eocene/Oligocene oxygen-isotope shift. Note $\delta^{18} \mathrm{O}$ decrease of Site 593 record in middle Oligocene in contrast to increase in Site 277 record. 


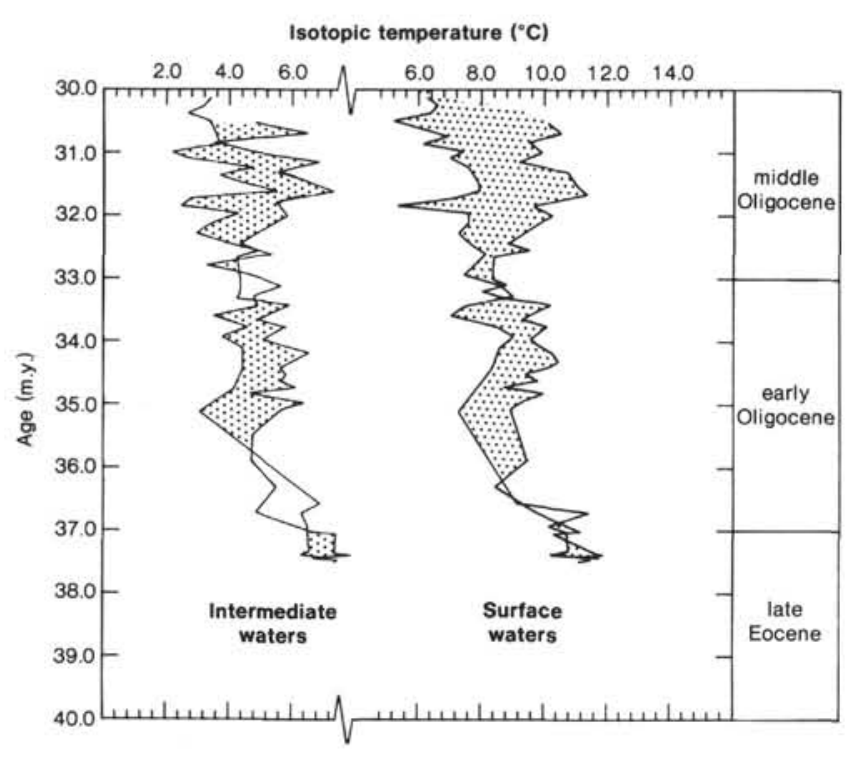

Figure 8. Plot of isotopic temperature gradient between Sites 277 and 593. Note reversal of gradient at $\sim 37-35.5 \mathrm{Ma}$ and at $\sim 33 \mathrm{Ma}$. Stippled areas, Site 277 cooler than Site 593; white areas, Site 277 warmer than Site 593.

all of the sedimentary record between $\sim 25$ and $80 \mathrm{Ma}$ on Marie Byrd Land (LeMasurier and Rex, 1982). Hyaloclastites thought to have been emplaced beneath ice sheets have been radiometrically dated as early Miocene and Oligocene in age, suggesting some ice accumulation during the Paleogene (LeMasurier, 1972). The first dated ice-rafted material in deep-sea sequences drilled around Antarctica is of late Oligocene age and is found in areas close to the continent within the Ross Sea embayment (Hayes and Frakes, 1975). Significant deposits of icerafted material have not been found at great distances from Antarctica in sediments older than middle Miocene. Site 278 on the Antarctic Convergence showed the first ice-rafted material at $\sim 15 \mathrm{Ma}$; the abundance increased rapidly in younger sediments (Margolis, 1975; Kennett, 1978). These data suggest that although the $\delta^{18} \mathrm{O}$ of water was probably not constant during the $\mathrm{Pa}$ leogene, it did not fluctuate greatly in response to large ice-sheet fluctuations.

Table 3 shows the temperature maxima and minima for the southwest Pacific sites calculated using a constant $\delta W$ of $-1.2 \%$. Benthic values range from a maximum of $9.0^{\circ} \mathrm{C}$ at Site 592 in the late Eocene $(\sim 40.7$ $\mathrm{Ma})$ to a low of $2.2^{\circ} \mathrm{C}$ in the middle Oligocene of Site 277 ( $\sim 31.0 \mathrm{Ma})$. Planktonic temperature estimates range from $13.0^{\circ} \mathrm{C}$ in the late Eocene $(\sim 39.1 \mathrm{Ma})$ at Site 592 to $5.2^{\circ} \mathrm{C}$ in the middle Oligocene of Site $277(\sim 30.5$ Ma). A comparison of these isotopic paleotemperature estimates with present-day values from the same regions reveals that modern waters at $50 \mathrm{~m}$ are warmer than the warmest values from the late Eocene through Oligocene. However, modern intermediate waters have temperatures similar to, but slightly warmer than, the coolest intermediate-water isotopic paleotemperatures estimated during the Oligocene from these sites (Garner, 1962, 1967; Craig et al., 1981).
Table 3. Maximal and minimal oxygen-isotope temperatures for each site assuming $\delta W=-1.2 \% 0$ in an ice-free world and present day temperatures at same locations.

\begin{tabular}{|c|c|c|c|c|c|}
\hline \multirow[b]{3}{*}{ Site } & \multicolumn{5}{|c|}{ Eocene-Oligocene isotopic temperatures $\left({ }^{\circ} \mathrm{C}\right)$} \\
\hline & \multicolumn{3}{|c|}{ Warmest } & \multicolumn{2}{|c|}{ Coolest } \\
\hline & \multicolumn{2}{|l|}{ Planktonic } & Benthic & Planktonic & Benthic \\
\hline 592 & \multicolumn{2}{|c|}{$12.96(39.1 \mathrm{Ma})$} & 8.98 (40.4 Ma) & $8.18(35.2 \mathrm{Ma})$ & $4.36(34.8 \mathrm{Ma})$ \\
\hline 593 & \multicolumn{2}{|c|}{$11.87(37.4 \mathrm{Ma})$} & $7.91(37.4 \mathrm{Ma})$ & $8.02(33.2 \mathrm{Ma})$ & $3.57(30.8 \mathrm{Ma})$ \\
\hline 277 & \multicolumn{2}{|c|}{$11.75(37.4 \mathrm{Ma})$} & $7.20(37.8 \mathrm{Ma})$ & $5.23(30.5 \mathrm{Ma})$ & $2.17(30.9 \mathrm{Ma})$ \\
\hline \multicolumn{6}{|c|}{ Present day } \\
\hline & Site & & Position & Surface & Intermediate \\
\hline \multicolumn{2}{|c|}{$\begin{array}{r}\text { NZOI \#Di } 2730 \\
\text { (Oct., 1950) }\end{array}$} & \multicolumn{2}{|c|}{$35^{\circ} 58^{\prime} \mathrm{S}, 163^{\circ} 39^{\prime} \mathrm{E}$} & $(50 \mathrm{~m}) 16.90^{\circ}$ & $(1170 \mathrm{~m}) 4.51^{\circ}$ \\
\hline \multicolumn{2}{|c|}{$\begin{array}{l}\text { NZOI \#A } 957 \\
(\text { Feb., 1964) }\end{array}$} & \multicolumn{2}{|c|}{$41^{\circ} 00^{\prime} \mathrm{S}, 165^{\circ} 55^{\prime} \mathrm{E}$} & $(51 \mathrm{~m}) 14.88^{\circ}$ & $(1090 \mathrm{~m}) 4.66^{\circ}$ \\
\hline \multicolumn{2}{|c|}{$\begin{array}{r}\text { GEOSECS } 279 \\
\text { (Feb., 1974) }\end{array}$} & \multicolumn{2}{|c|}{$55^{\circ} 60^{\prime} \mathrm{S}, 170^{\circ} 60^{\prime} \mathrm{E}$} & $(50 \mathrm{~m}) 7.40^{\circ}$ & $(1103 \mathrm{~m}) 2.74^{\circ}$ \\
\hline
\end{tabular}

If there had been accumulation of ice on Antarctica during the time represented by these sediments, there would have been enrichment of ${ }^{18} \mathrm{O}$ in the global ocean, making the paleotemperatures even warmer than those calculated using a constant $\delta W$ of $-1.2 \%$. An enrichment of global $\delta W$ values resulting from ice formation would appear as a synchronous enrichment in the surface and intermediate (and deep) oxygen-isotope values at every site (Shackleton and Opdyke, 1973). Each site in the southwest Pacific exhibits strong parallelism of planktonic and benthic oxygen-isotope records until $\sim 33$ $\mathrm{Ma}$, at which time they record the coolest isotopic paleotemperatures. After this, however, the records from different sites diverged. We interpret this pattern to be the result of the combined effects of ice accumulation and the progressive decoupling of surface-water temperatures resulting from paleocirculation changes within the region. Clear evidence for the permanent presence of ice sheets is seen only from the middle Miocene $(\sim 15 \mathrm{Ma})$ to the present day. Future drilling in the Antarctic region should help define the nature of large ice accumulations, if any, on Antarctica during the Paleogene and hence assist in the interpretation of absolute paleotemperatures using stable-isotope data.

\section{TEMPERATURE GRADIENTS}

The present-day temperature gradient between $35^{\circ} \mathrm{S}$ ( Site 593) and $55^{\circ} \mathrm{S}(\sim$ Site 277$)$ is $9.5^{\circ} \mathrm{C}$ at $50 \mathrm{~m}$ and $1.8^{\circ} \mathrm{C}$ at $\sim 1000 \mathrm{~m}$ (Garner, 1962, 1967; Craig et al., 1981). Throughout the Oligocene, the isotopic paleotemperature at Site 277 was usually cooler than that at Sites 592 or 593 , which exhibited similar paleotemperatures (see Table 3 ). Figure 8 shows the changing surface and intermediate gradients for the latest Eocene through middle Oligocene between Sites 277 and 593. In the late Eocene, northern Sites 592 and 593 recorded temperatures very similar to those at Site 277 . By $35 \mathrm{Ma}$, in the early Oligocene, a gradient of $\sim 1.5^{\circ} \mathrm{C}$ had developed in both intermediate and surface waters. The surface-water gradients remained at $\sim 1.5^{\circ} \mathrm{C}$ until $33 \mathrm{Ma}$ while the in- 
termediate-water gradient fluctuated around $1.0^{\circ} \mathrm{C}$. The remaining record is characterized by an increasing offset between these sites. A maximum gradient of $4.0^{\circ} \mathrm{C}$ for surface and $2.4^{\circ} \mathrm{C}$ for intermediate waters was reached at 31-30 Ma, at which time the planktonic foraminifers at southern Site 277 recorded temperatures nearly as cool as the benthic foraminifers at northern Site 593 (Fig. 8). The greatest amount of latitudinal difference documented in this study occurred at the end of our comparable data at the base of the Site 277 hiatus ( $~ 30 \mathrm{Ma}$, middle Oligocene). The late Oligocene record at Site 593 suggested no major warming or cooling (Fig. 4).

The major steps in the Oligocene development of Southern Ocean latitudinal thermal gradients began at times of "inversion" in the gradient record at 36.0 and $33.0 \mathrm{Ma}$. These changes in the thermal gradient generally support the paleoceanographic history of the southwest Pacific sector of the Southern Ocean developed by Kennett et al. (1975) and by Kennett $(1977,1978)$. The proposed paleoceanographic history of the region is summarized in the series of maps shown in Figure 9A-D.

In the late Eocene (Fig. 9A) no Circum-Antarctic Current existed to interfere with the influence of the southward-flowing warm-subtropical arm of the South Pacific gyre (East Australian Current). These warm-subtropical waters were transported close to Antarctica, warming this region and preventing the development of extensive seasonal sea ice (Kennett, 1977). The influence of this gyre resulted in similar temperatures at all three sites during the late Eocene, as recorded by the overlapping values of the oxygen-isotope records.

Kennett et al. (1975) showed that the first high-latitude surface-water communication between the South Indian and South Pacific Oceans occurred in the latest Eocene across the shallow, subsiding South Tasman Rise (Fig. 9B). The opening of the Tasmanian Seaway at shallow depths was a major step in the development of the Circum-Antarctic Current. This allowed passage of relatively cool Indian Ocean waters into the South Pacific, which led to cooling of waters in the South Pacific sector of the Southern Ocean and an initial decoupling of the warm-subtropical gyre from the Southern Ocean (Kennett, 1977, 1978). As a result, the first extensive sea ice and the initial production of cold, dense psychrospheric bottom waters are inferred to have begun in close association with the Eocene/Oligocene boundary in areas adjacent to the Antarctic continent (Shackleton and Kennett, 1975; Kennett, 1978). Thus, the Eocene/Oligocene boundary event, as delineated by the $\delta^{18} \mathrm{O}$ shift, is not an isolated event but rather marks the crossing of a threshold in the sequential climatic deterioration seen in the Paleogene paleoclimatic record (Kennett, 1978; Corliss et al., 1984). It has also been proposed that the initial development of the two-layered, thermohaline-driven (psychrospheric) ocean preceded the Eocene/Oligocene boundary, occurring in the latest Eocene ( $\sim 40 \mathrm{Ma})$ and that the $\delta^{18} \mathrm{O}$ shift at the Eocene/Oligocene boundary marks the shallow water manifestation of this essentially deep-water event (Benson et al., in press). The intermediate records available from the Southwest Pacific cannot resolve this issue.
The continuing separation of Antarctica from Australia led to the further development of the Circum-Antarctic Current. Deep-water circulation developed in the middle to late Oligocene (Fig. 9C), as a deep passage formed south of the South Tasman Rise (Kennett et al., 1975 ) and the Drake Passage opened (Barker and Burrell, 1977).

Our oxygen-isotope data clearly record the evolution of this system. The paleotemperature difference between Site 277 and the more northern sites continued to increase, in surface waters, through the early to middle Oligocene, except for a reversal of the gradient at $\sim 33$ Ma. This divergence resulted from further cooling of high-latitude surface waters as the Southern Ocean continued to expand northward.

A major development in the thermal differentiation occurred $\sim 33 \mathrm{Ma}$ between Site 277 and the northern sites in both surface and intermediate waters as the thermal gradient between these two regions significantly and rapidly increased (Figs. 7 and 8). This is interpreted to reflect a major reorganization of Southern Ocean circulation as proposed earlier by Kennett et al. (1975) and by Kennett (1975) when deep Circum-Antarctic Circulation developed through the Tasmanian Seaway. This led to the formation of widespread hiatuses in the high southern latitudes, northward displacement of the siliceous/calcareous sediment boundary, and the beginning of essentially uninterrupted Neogene biogenic sediment deposition in the Coral and Tasman seas. Resulting intensification of the Circum-Antarctic Current led to further decoupling between the warm-subtropical South Pacific gyre and the cold circumpolar circulation. This decoupling proceeded in both surface and intermediate waters. High-latitude surface waters continued to cool, while those at middle latitudes warmed. At the same time, high-latitude intermediate waters rapidly cooled while those at temperate latitudes gradually warmed. The decoupling of these systems at both surface and intermediate depths led to the parallel development of increasingly cool subpolar regions and increasingly warm subtropics.

During the Miocene, continued decoupling resulted in intensified latitudinal thermal gradients, which doubled from 6 to $12^{\circ} \mathrm{C}$ between the tropics and the subAntarctic (Loutit et al., 1984).

\section{BIOGEOGRAPHY}

In the modern ocean there exist a number of surfacewater masses bounded by oceanographic fronts that are marked by distinct planktonic fauna and flora. These bioprovinces are arranged with a distinct latitudinal zonality and provide an alternate line of evidence for the water-mass evolution we have proposed. As the pole-toequator thermal gradient developed during the Cenozoic, there should have been an associated evolution of latitudinal biogeographic zonality. In the present ocean, Site 277 is well within the subantarctic biogeographic province; in contrast, Sites 592 and 593 lie within the temperate (cool subtropical) biogeographic province. Fauna and flora associated with these present-day water masses are quite distinct, the boundary coincides with 


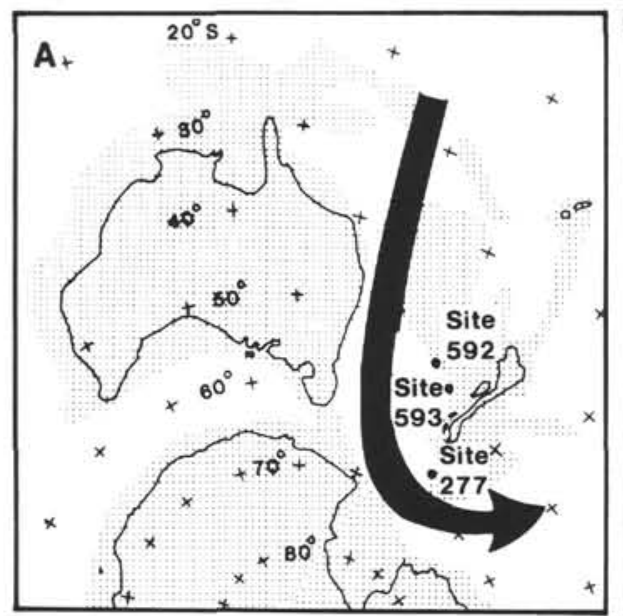

late Eocene

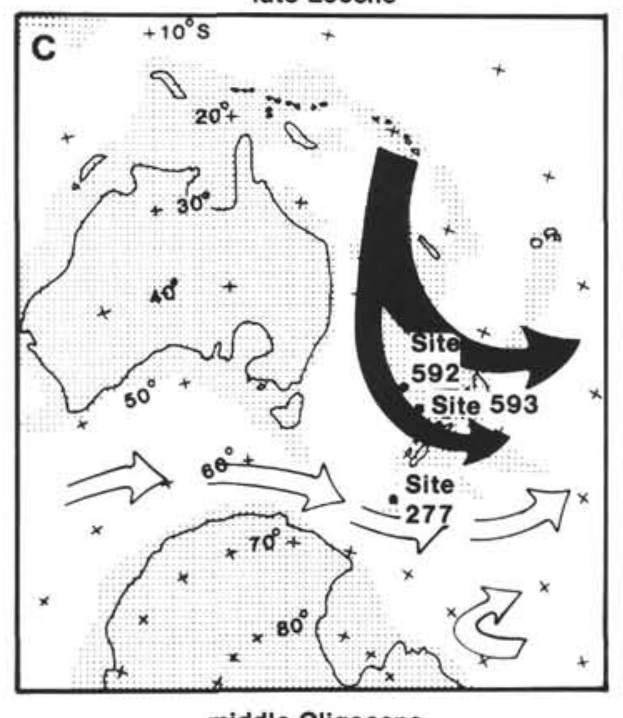

middle Oligocene

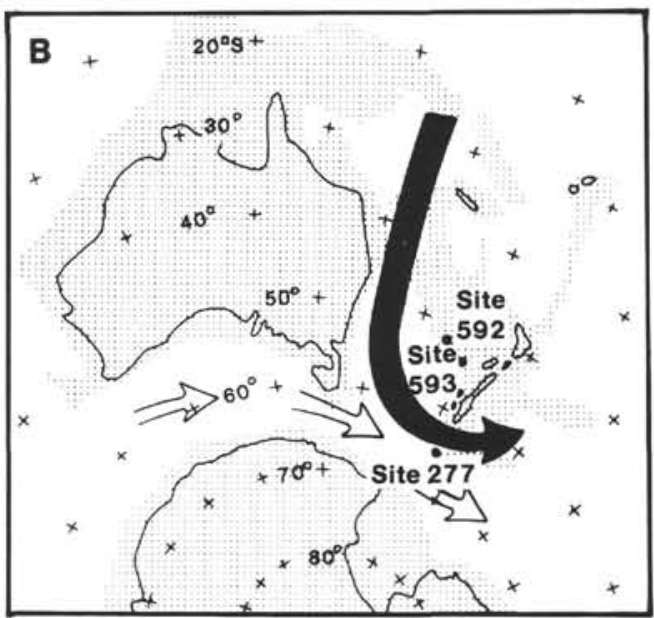

early Oligocene

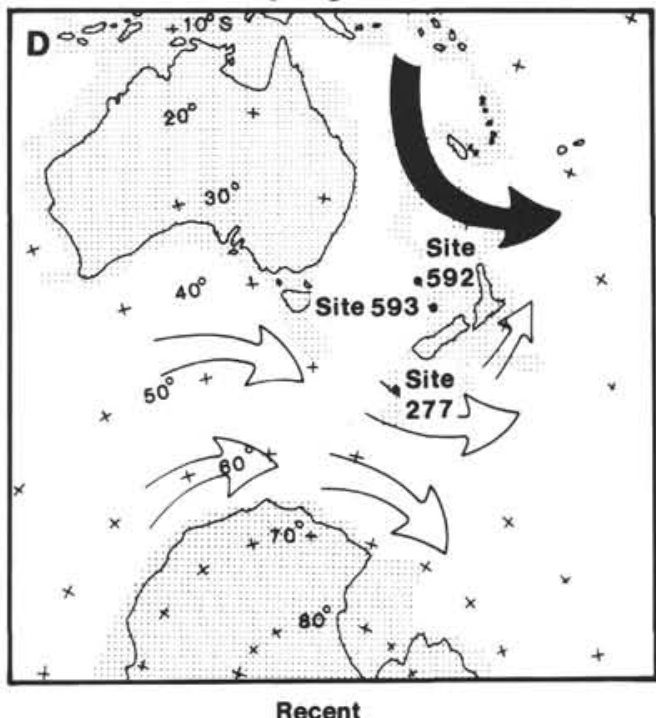

Figure 9. Proposed model for decoupling of ocean currents affecting temperatures at Sites 592 and 593 versus Site 277. Dark arrows denote warm currents, open arrows denote cool/cold currents, width of arrow indicative of current strength. Land areas and shallow ridges and rises as marked.

the Subtropical Convergence. During the Eocene and Oligocene, these separate biogeographic provinces had not yet developed. Planktonic foraminiferal assemblages at Sites 277 and 593/592 are generally similar during this time and contain most of the same taxa, but in differing proportions (Jenkins, 1975; Jenkins and Srinivasan, this volume). Warm-water elements are more abundant in the northern sites relative to the south, but the assemblages do not suggest the presence of an oceanographic front between the regions as in the modern ocean. The study of the planktonic microfossil sequence at Site 594 , drilled in the present-day northern subantarctic waters just south of the Subtropical Convergence, has suggested that this oceanic front developed during the middle Miocene. The Antarctic Convergence (Polar Front) had developed south of Site 277 by the earliest Oligocene, as seen by the faunal assemblages in Hole 267B at $59^{\circ} \mathrm{S}$ latitude. This front was marked by major faunal differences between relatively high-diversity subantarctic planktonic foraminiferal assemblages to the north and very low-diversity polar assemblages to the south (Kaneps, 1975).

\section{CONCLUSIONS}

Oxygen-isotope data document the development of thermal gradients during the Oligocene in the southwest Pacific between subantarctic and temperate latitudes. Isotopic temperature records from these sites diverged in three major steps beginning in the early Oligocene. Late Eocene values overlap; early to middle Oligocene values exhibit a slight divergence as the result of continued temperature decreases at high latitudes but not at temperate latitudes; the middle Oligocene values exhibit major and rapid divergence of both planktonic and benthic signals as the subantarctic region continued to cool and the temperate regions warmed.

This oxygen-isotope history was closely tied to the development of the Circum-Antarctic Current. In the late Eocene, the entire area was bathed by southerlyflowing warm-subtropical gyre waters, uninterrupted by 
the Circum-Antarctic Current, which had not yet developed. The beginning of latitudinal thermal differentiation occurred after the oxygen-isotope shift associated with the Eocene/Oligocene boundary and is believed to have been related to the development, in the latest Eocene, of surface-water communication between the South Indian and South Pacific sectors. This began to decouple the warm subtropical gyres from the high southern latitudes leading to a cooling of surface- and bottomwater masses. A further major temperature divergence occurred at $33 \mathrm{Ma}$, when the Circum-Antarctic Current was able to flow south of the South Tasman Rise and affect both deep and shallow waters. This study suggests that there were accumulations of ice during the middle Oligocene, but the diverging oxygen-isotope records after $\sim 33 \mathrm{Ma}$ argue against the establishment of a permanent ice sheet at that time. Further intensification of the cold polar current continued to decouple temperate from subantarctic surface regimes and led to a warming of temperate surface-water masses.

Despite the increase in temperature gradients between Antarctic and temperate regions during the Oligocene, biogeographic similarities in calcareous microfossils suggest that the Subtropical Convergence had not yet formed by the end of the Paleogene. Biostratigraphic evidence suggests formation of this convergence in the middle Miocene. Biogeographic changes, however, do support the existence and development of temperature differences between these latitudes in the Paleogene.

\section{ACKNOWLEDGMENTS}

We thank Nancy Meader, Karin Nelson, Robin Rice, Jenny Martin, and Joe Orchardo for their assistance in drafting and editing. Discussion of these ideas with Paul Abell, Allan Cain, and Margaret Leinen was very helpful as was a review by Dave Johnson. Special appreciation is rendered to Ken Miller and Margaret Leinen for their thorough reviews of the manuscript. This research was supported by the National Science Foundation grant \#DPP81-12615 from the Division of Polar Programs.

\section{REFERENCES}

Barker, P. T., and Burrell, J., 1977. The opening of Drake Passage. Mar. Geol., 25:15-34.

Benson, R. H., Chapman, R. E., and Deck, L. T., 1984. Paleoceanographic events and deep-sea ostracods. Science, 224:1334-1336.

Berggren, W. A., Kent, D. V., and Flynn, J. J., in press. Paleogene geochronology and chronostratigraphy. In Snelling, N. J. (Ed.), Geochronology and the Geologic Time Scale. Geol. Soc. Lond. Spec. Pap.

Blattner, P., and Hulston, J. R., 1978. Proportional variations of geochemical $\delta^{18} \mathrm{O}$ scales-An interlaboratory comparison. Geochim. Cosmochim. Acta, 42:59-62.

Brass, G. W., Southam, J. R., and Peterson, W. H., 1982. Warm, saline bottom water in the ancient ocean. Nature (London), 296: 620-623.

Corliss, B. H., Aubry, M.-P., Berggren, W. A., Fenner, J. M., Keigwin, L. D., Jr., and Keller, G., 1984. The Eocene/Oligocene Boundary event in the deep sea. Science, 226:806-810.

Craig, H., 1957. Isotopic standards for carbon and oxygen and correction factors for mass-spectrometric analysis of carbon dioxide. Geochim. Cosmochim. Acta, 12:133-140.

Craig, H., Broecker, W. S., and Spencer, D., 1981. Geosecs Pacific Expedition: Hydrographic Data: Washington (Natl. Sci. Found.).

Frakes, L. A., 1979. Climates throughout Geologic Time. New York (Elsevier).
Garner, D. M., 1962. Analysis of hydrological observations in the New Zealand Region, 1874-1955. N. Z. Oceanogr. Inst. Mem., 9: $1-45$.

1967. Hydrology of the south-east Tasman Sea. N. Z. Oceanogr. Inst. Mem., 48:9-49.

Gordon, A. L., 1972. On the interaction of the Antarctic Circumpolar Current and the Macquarie Ridge. In Hayes, D. E. (Ed.), Antarctic Oceanology II, The Australian-New Zealand Sector. Am. Geophys. Union Antarct. Res. Ser., 19:71-78.

Graham, D. W., Corliss, B. H., Bender, M. L., and Keigwin, L. D., Jr., 1981. Carbon and oxygen isotopic disequilibria of Recent deepsea benthic foraminifera. Mar. Micropaleontol., 6:483-497.

Hayes, D. E., and Frakes, L. A., 1975. General synthesis, Deep Sea Drilling Project Leg 28. In Hayes, D. E., Frakes, L. A., et al., Init. Repts. DSDP, 28: Washington (U.S. Govt. Printing Office), 919-942.

1975. Cenozoic planktonic foraminiferal biostratigraphy of the southwestern Pacific and Tasman Sea-DSDP Leg 29. In Kennett, J. P., Houtz, R. E., et al., Init. Repts. DSDP, 29: Washington (U.S. Govt. Printing Office), 449-468.

Jenkins, D. G., 1975. Initiation of the proto circum-antarctic current. Nature (London), 252:371-373.

Kaneps, A. G., 1975. Cenozoic planktonic foraminifera from Antarctic deep-sea sediments, Leg 28. In Hays, D. E., Frakes, L. A., et al., Init. Repts. DSDP, 28: Washington (U.S. Govt. Printing Office), 573-584.

Keigwin, L. D., Jr., 1980. Paleoceanographic change in the Pacific at the Eocene-Oligocene Boundary. Nature (London), 287:722-725.

Keigwin, L. D., Jr., and Keller, G., 1984. Middle Oligocene cooling from Equatorial Pacific DSDP Site 77B. Geology, 12:16-19.

Kennett, J. P., 1977. Cenozoic evolution of Antarctic glaciation, the circum-antarctic ocean, and their impact on global paleoceanography. J. Geophys. Res., 82:3843-3860.

1978. The development of planktonic biogeography in the Southern Ocean during the Cenozoic. Mar. Micropaleontol., 3: 301-345.

1982. Marine Geology. New Jersey (Prentice-Hall, Inc.).

Kennett, J. P., Houtz, R. E., Andrews, P. B., Edwards, A. R., Gostin, V. A., Hajos, M., Hampton, M., Jenkins, D. G., Margolis, S. V., Ovenshine, A. T., and Perch-Nielsen, K., 1975. Cenozoic paleoceanography in the southwest Pacific Ocean, Antarctic glaciation and the development of the circum-antarctic current. In Kennett, J. P., Houtz, R. E., et al., Init. Repts. DSDP, 29: Washington (U.S. Govt. Printing Office), 1155-1169.

Kvasov, D. D., and Verbitsky, M. Y., 1981. Causes of Antarctic Glaciation in the Cenozoic. Quat. Res., 15:1-17.

LeMasurier, W. E., 1972. Volcanic record of Cenozoic Glacial History of Marie Byrd Land. In Adie, R. J. (Ed.), Antarctic Geology and Geophysics: Oslo (Scand. University Books), pp. 251-259.

LeMasurier, W. E., and Rex, D. C., 1982. Rates of uplift and the scale of ice level instabilities recorded by volcanic rocks in Marie Byrd Land, West Antarctica. In Craddock, C. (Ed.), Antarctic Geoscience. Madison (Univ. Wisconsin Press), 725-734.

Loutit, T. S., Kennett, J. P., and Savin, S. M., 1984. Miocene equatorial and southwest Pacific paleoceanography from stable isotopeevidence. Mar. Micropaleontol., 8:215-223.

Margolis, S. V., 1975. Paleoglacial history of Antarctica inferred from analyses of Leg 29 sediments by scanning-electron microscopy. In Kennett, J. P., Houtz, R. E., et al., Init. Repts. DSDP, 29: Washington (U.S. Govt. Printing Office), 1039-1048.

Matthews, R. K., and Poore, R. Z., 1980. Tertiary delta O-18 record and glacio-eustatic sea-level fluctuations. Geology, 8:501-504.

Miller, K. G., and Fairbanks, R. G., 1983. Evidence for OligoceneMiddle Miocene abyssal circulation changes in the western North Atlantic. Nature (London), 306:250-253.

Miller, K. G., and Thomas, E., in press. Late Eocene to Oligocene benthic foraminiferal isotope record, Site 574, equatorial Pacific. In Mayer, L., Theyer, F., et al., Init. Repts. DSDP, 85: Washington (U.S. Govt. Printing Office).

Poore, R. Z., and Matthews, R. K., 1984. Late Eocene-Oligocene oxygen and carbon isotopic record from South Atlantic ocean, Deep Sea Drilling Project Site 522. In Hsü, K. J., LaBrecque, J. L., et al., Init. Repts. DSDP, 73: Washington (U.S. Govt. Printing Office), 725-736. 
Sancetta, C., 1979. Paleogene Pacific microfossils and paleoceanography. Mar. Micropaleontol., 4:363-398.

Savin, S. M., 1977. The history of the Earth's surface temperature during the past 100 m.y. Annu. Rev. Earth Planet. Sci., 5:319-355.

Savin, S. M., Douglas, R. G., Keller, G., Killingley, J. S., Shaughnessy, L., Sommer, M. A., Vincent, E., and Woodruff, F., 1981. Miocene benthic foraminiferal isotope records: A synthesis. Mar. Micropaleontol., 6:423-450.

Savin, S. M., Douglas, R. G., and Stehli, F. G., 1975. Tertiary marine paleotemperatures. Geol. Soc. Am. Bull., 86:1499-1510.

Savin, S. M., and Yeh, H. W., 1981. Stable isotopes in ocean sediments. In Emiliani, C. (Ed.), The Sea (Vol. 7): The Oceanic Lithosphere: New York (Wiley-Interscience), 1521-1554.

Sclater, J. G., Meinke, L., Bennett, A., and Murphy, C., in press. The depth of the ocean through the Neogene. In Kennett, J. P. (Ed.), The Miocene Ocean: Paleoceanography and Biogeography (CENOP). Mem. Geol. Soc. Am., 163

Shackleton, N. J., Hall, M. A., and Boersma, A., 1984. Oxygen and carbon isotope data from Leg 74 foraminifers. In Moore, T. C., Jr., Rabinowitz, P. D., et al., Init. Repts. DSDP, 74: Washington (U.S. Govt. Printing Office), 599-612.

Shackleton, N. J., and Kennett, J. P., 1975. Paleotemperature history of the Cenozoic and the initiation of Antarctic glaciation: oxygen and carbon isotope analyses in DSDP Sites 277, 279, and 281. In Kennett, J. P., Houtz, R. E., et al., Init. Repts. DSDP, 29: Washington (U.S. Govt. Printing Office), 743-756.

Shackleton, N. J., and Opdyke, N. D., 1973. Oxygen isotope and palaeomagnetic stratigraphy of equatorial Pacific core V28-238: Oxygen isotope temperatures and ice volumes on a $10^{5}$ year and $10^{6}$ year scale. Quat. Res., 3:39-55.

Wise, S. W., Ciesielski, P. F., MacKenzie, D. T., Wind, F. H., Busen, K. E., Gombos, A. M., Haq, B. U., Lohmann, G. P., Tjalsma, R. C., Harris, W. K., Hedlund, R. W., Beju, D. N., Jones, D. W., Plafker, G., and Sliter, W. V., 1982. Paleontologic and paleoenvironmental synthesis for the southwest Atlantic ocean basin based on Jurassic to Recent faunas and floras from the Falkland Plateau. In Craddock, K. (Ed.), Antarctic Geoscience. Madison (Univ. of Wisconsin Press), 155-163.

Wolfe, J. A., 1971. Tertiary climatic fluctuations and methods of analysis of Tertiary floras. Paleogeogr., Paleoclimatol., Paleoecol., 9: 27-57.

Woodruff, F., and Douglas, R. G., 1981. Response of deep sea benthic foraminifera to Miocene paleoclimatic events, DSDP Site 289. Mar. Micropaleontol., 6:617-632.

Date of Initial Receipt: 10 August 1984

Date of Acceptance: 7 December 1984

\section{APPENDIX \\ Calibration of the URI Stable Isotope Standards \\ J. R. Orchardo}

Calibration of the University of Rhode Island's mass spectrometry laboratory reference gas to PDB was accomplished by analysis of national and international standards. These were NBS-20, NBS-19, TKL-1, B-1, Fletton Clay, Brown Yule Marble, and Carrara Marble. Each standard was reacted in fresh $100 \%$ orthophosphoric acid at 50 $\pm 0.5^{\circ} \mathrm{C}$. purified, and analysed on a VG Micromass $602 \mathrm{D}$ mass spectrometer. The data were corrected following Craig (1957). Conversion to per mil values with respect to PDB was done in two different ways. First, the intercept of a regression of the measured versus literature data was used to correct to PDB. This minimized the uncertainty of the value of NBS-20 to PDB presently in the literature. The second method corrected each standard using only its measured value and the literature value of NBS-20 found in Blattner and Hulston (1978).

It must be noted that the B-1 standard that URI analyzes is a coarse size fraction of that standard. It has recently come to our attention that the delta values of this size fraction differ from the values obtained from the fine size fraction which is more widely analyzed (D. Price, personal communication, 1983). Therefore, we present the B-1 data with respect to our own laboratory calibration of PDB and not with respect to any literature value to PDB.

With the exception of the $\delta^{13} \mathrm{C}$ values of TKL-1 and Fletton Clay, the URI results compare well with values reported in the literature (see Table 1).

Table 1. Results of analyses of national and international standards.

\begin{tabular}{|c|c|c|c|c|}
\hline Standard & $\begin{array}{c}\text { URI } \\
\text { measured }\end{array}$ & $\begin{array}{l}\text { Correction by } \\
\text { regression } \\
\text { to } \mathrm{PDB}\end{array}$ & $\begin{array}{l}\text { Correction by } \\
\text { NBS-20 } \\
\text { to PDB }\end{array}$ & $\begin{array}{l}\text { Literature } \\
\text { value to } \\
\text { PDB }\end{array}$ \\
\hline \multicolumn{5}{|l|}{$\delta^{18} \mathrm{O}$} \\
\hline NBS-20 & $-3.55 \pm 0.02$ & -4.14 & - & -4.18 \\
\hline NBS-19 & $-1.52 \pm 0.02(4)$ & -2.11 & -2.15 & -2.19 \\
\hline TKL-1 & $-3.56 \pm 0.06(5)$ & -4.15 & -4.19 & -4.26 \\
\hline B-1 (coarse fraction) & $0.88 \pm 0.04$ (4) & 0.31 & 0.23 & - \\
\hline Fletton Clay & $0.32 \pm 0.02(6)$ & -0.27 & -0.31 & -0.24 \\
\hline Brown Yule Marble & $-6.00 \pm 0.06(5)$ & -6.59 & -6.63 & -6.54 \\
\hline Carrara Marble & $-1.29 \pm 0.05(5)$ & -1.88 & -1.92 & -1.81 \\
\hline \multicolumn{5}{|l|}{${ }_{b^{13}} \mathrm{C}$} \\
\hline NBS-20 & $-2.28 \pm 0.04$ & -1.05 & - & -1.07 \\
\hline NBS-19 & $0.71 \pm 0.02(4)$ & 1.93 & 1.88 & 1.92 \\
\hline TKL-1 & $-3.17 \pm 0.09$ (5) & -1.95 & -2.00 & -1.69 \\
\hline B-1 (coarse fraction) & $-0.58 \pm 0.04(4)$ & 0.64 & 0.59 & - \\
\hline Fletton Clay & $1.02 \pm 0.03(6)$ & 2.24 & 2.29 & 1.91 \\
\hline Brown Yule Marble & $-3.54 \pm 0.05(5)$ & -2.32 & -2.37 & -2.29 \\
\hline Carrara Marble & $0.94 \pm 0.02(5)$ & 2.16 & 2.11 & 2.16 \\
\hline
\end{tabular}

